\title{
Hypothesis
}

\section{Two Motors and One Spring: Hypothetic Roles of Non-Muscle Myosin II and Submembrane Actin-Based Cytoskeleton in Cell Volume Sensing}

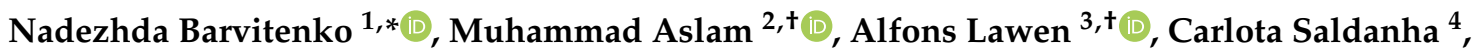 \\ Elisaveta Skverchinskaya ${ }^{5}{ }^{\circledR}$, Giuseppe Uras ${ }^{6}$, Alessia Manca ${ }^{7}$ and Antonella Pantaleo ${ }^{7, *}(\mathbb{C})$ \\ Citation: Barvitenko, N.; Aslam, M.; \\ 1 Independent Researcher, 191014 Saint-Petersburg, Russia \\ 2 Department of Internal Medicine I, Experimental Cardiology, Justus Liebig University, \\ 35392 Giessen, Germany; muhammad.aslam@physiomed.jlug.de \\ 3 Department of Biochemistry and Molecular Biology, School of Biomedical Sciences, Monash University, \\ Clayton, VIC 3800, Australia; alfons.lawen@monash.edu \\ 4 Institute of Biochemistry, Institute of Molecular Medicine, Faculty of Medicine University of Lisbon, \\ 1649-028 Lisboa, Portugal; carlotasaldanha@fm.ul.pt \\ 5 Sechenov Institute of Evolutionary Physiology and Biochemistry, 194223 St. Petersburg, Russia; \\ lisarafail@mail.ru \\ 6 Department of Clinical and Movement Neurosciences, Institute of Neurology, University College London, \\ London NW3 2PF, UK; g.uras@ucl.ac.uk \\ 7 Department of Biomedical Science, University of Sassari, Viale San Pietro 43/B, 07100 Sassari, Italy; \\ alessia_manca@hotmail.it \\ * Correspondence: nbarvitenko@mail.ru (N.B.); apantaleo@uniss.it (A.P.) \\ + These authors contributed equally.
} Lawen, A.; Saldanha, C.; Skverchinskaya, E.; Uras, G.; Manca, A.; Pantaleo, A. Two Motors and One Spring: Hypothetic Roles of Non-Muscle Myosin II and Submembrane Actin-Based Cytoskeleton in Cell Volume Sensing Int. J. Mol. Sci. 2021, 22, 7967. https://doi.org/10.3390/ ijms22157967

Academic Editor: Dario Mizrachi

Received: 29 June 2021

Accepted: 23 July 2021

Published: 26 July 2021

Publisher's Note: MDPI stays neutral with regard to jurisdictional claims in published maps and institutional affiliations.

Copyright: (C) 2021 by the authors Licensee MDPI, Basel, Switzerland. This article is an open access article distributed under the terms and conditions of the Creative Commons Attribution (CC BY) license (https:// creativecommons.org/licenses/by/ $4.0 /)$
Abstract: Changes in plasma membrane curvature and intracellular ionic strength are two key features of cell volume perturbations. In this hypothesis we present a model of the responsible molecular apparatus which is assembled of two molecular motors [non-muscle myosin II (NMMII) and protrusive actin polymerization], a spring [a complex between the plasma membrane (PM) and the submembrane actin-based cytoskeleton (smACSK) which behaves like a viscoelastic solid] and the associated signaling proteins. We hypothesize that this apparatus senses changes in both the plasma membrane curvature and the ionic strength and in turn activates signaling pathways responsible for regulatory volume increase (RVI) and regulatory volume decrease (RVD). During cell volume changes hydrostatic pressure (HP) changes drive alterations in the cell membrane curvature. HP difference has opposite directions in swelling versus shrinkage, thus allowing distinction between them. By analogy with actomyosin contractility that appears to sense stiffness of the extracellular matrix we propose that NMMII and actin polymerization can actively probe the transmembrane gradient in HP. Furthermore, NMMII and protein-protein interactions in the actin cortex are sensitive to ionic strength. Emerging data on direct binding to and regulating activities of transmembrane mechanosensors by NMMII and actin cortex provide routes for signal transduction from transmembrane mechanosensors to cell volume regulatory mechanisms.

Keywords: cell volume; swelling; shrinkage; non-muscle myosin II; actin cortex; actin polymerization; mechanosensors; proliferation; apoptosis; migration

\section{Introduction}

Cell fate and functioning, e.g., proliferation, migration, apoptosis, are accompanied and critically determined by appropriate changes in cell volume [1-8]. Changes occurring in the cell under exposure to osmotic challenge consist of modifications in the membrane curvature and alterations in intracellular ionic strength. In response to shrinkage the cell induces regulatory volume increase (RVI) which involves activation of $\mathrm{Na}^{+}-\mathrm{K}^{+}-2 \mathrm{Cl}^{-}$ cotransporters (NKCC), $\mathrm{Na}^{+} / \mathrm{H}^{+}$exchangers (NHE), $\mathrm{Na}^{+}$channels and uptake of organic 
osmolytes. Cell swelling leads to regulatory volume decrease (RVD) mediated by activation of $\mathrm{K}^{+}$and $\mathrm{Cl}^{-}$ion channels, $\mathrm{K}^{+}-\mathrm{Cl}^{-}$cotransporters (KCC) and the efflux of organic osmolytes [1-8].

There are surprising multiple and diverse signaling molecules participating in signal transduction from volume sensor(s) onto executive ion transport proteins. Serine/threonine kinases and phosphatases, protein tyrosine kinases, mitogen-activated protein kinases (MAPKs), small GTPases of the Rho family, reactive oxygen species (ROS) participate in shrinkage- and swelling-induced signaling $[2,7,9,10]$.

Among members of the superfamily of myosin motors we only discuss non-muscle myosin II (NMMII). Experimental data on involvement of NMMII in cell volume regulation are rather scarce, but it has been reported that cytoplasts from Ehrlich ascites tumor cells lack both, NMMII and shrinkage-induced activation of the NKCC1 [11]. Phosphorylation of myosin light chain by myosin light chain kinase (MLCK) was elevated and decreased under cell shrinkage and swelling, respectively, in endothelial cells [12]. The basal activity of myosin ATPase appears to be permissive for activation of NKCC by cell shrinkage [13,14].

Here, we discuss the complex consisting of the plasma membrane (PM) and the submembrane actin-based cytoskeleton (smACSK), which we shall refer to as PM-smACSK. We regard PM-smACSK as a viscoelastic solid with four effects on active ATP-consuming cell volume sensing: firstly, NMMII-generated pulling force directed into inside of the cell. Secondly, a force of protrusive actin polymerization within the PM-smACSK would generate a pushing force directed out from the cell. Thirdly, PM-smACSK would be a rigid structure that should be pulled in by NMMII or pushed out by F-actin assembly. Fourthly, PM-smACSK is considered as being a spring. Indeed, spring-like behavior seems to be necessary for a sensor of changes in membrane curvature to function because it must return to its baseline conformation upon release of the stimulus, i.e., when the cell restores its normal volume and shape. Morishima et al. have shown that the swelling-induced activation of the $\mathrm{Cl}^{-}$channel depends on the spring energy of the membrane [15].

We hypothesize that NMMII and force of actin-based protrusions can probe balance of hydrostatic pressures (HPs) across the plasma membrane as well as changes in ionic strength in submembrane compartments. To function as sensors of the cell volume NMMII and the actin-based motor should meet at least four requirements: (i) to be controlled by the same signaling pathways that determine cell fate (discussed in Section 2), (ii) to unambiguously distinguish between swelling and shrinkage (discussed in Section 3), (iii) to sense changes in the intracellular ionic strength (discussed in Section 4), and (iv) to possess mechanisms of transduction of information from NMMII and F-actin to signaling pathways mediating RVI and RVD (discussed in Section 5).

\section{Tuning of Cell Volume Set Point by Cell Program (Proliferation, Apoptosis, Migration) via Control of NMMII, F-Actin Protrusive Force and PM-smACSK}

Cell fate determines the whole architecture and biomechanics of the CSK. Here we subdivide the whole CSK into the bulk CSK, spanning through the cell interior, and the submembrane CSK which underlines the PM. Stimuli that switch on a cell program (e.g., proliferation, migration, apoptosis) activate multiple signaling pathways that regulate the assembly of the actin-based CSK, and the architecture of the smACSK determines the PM-smACSK biomechanics and cell volume sensing (Figure 1).

\subsection{NMMII, a Pulling Motor}

\subsubsection{NMMII, Common Features and Regulation}

NMMII is an actin-based molecular motor. It is a heterohexamer comprised of two heavy chains (HCs), two essential light chains (ELCs) and two regulatory light chains (RLCs) [16-19]. Each heavy chain consists of 3 domains: the N-terminal globular head harboring the ATPase activity responsible for force generation and actin binding; the neck domain which binds to ELCs and RLCs, and the C-terminal $\alpha$-helical rod domain with a nonhelical tail-piece needed for thick filament formation and cargo binding [16-19]. 
This heterohexameric complex of 2 HCs, 2 ELCs and 2 RLCs is referred to as NMMII monomer, since it represents a functional unit, and NMMII monomers undergo assembly into filaments and stacks [19] (Figure 2). Depending on their HCs there are three isoforms of NMMII (NMMIIA, NMMIIB and NMMIIC) that differ in tissue distribution, function, intracellular localization and regulation [16-19].

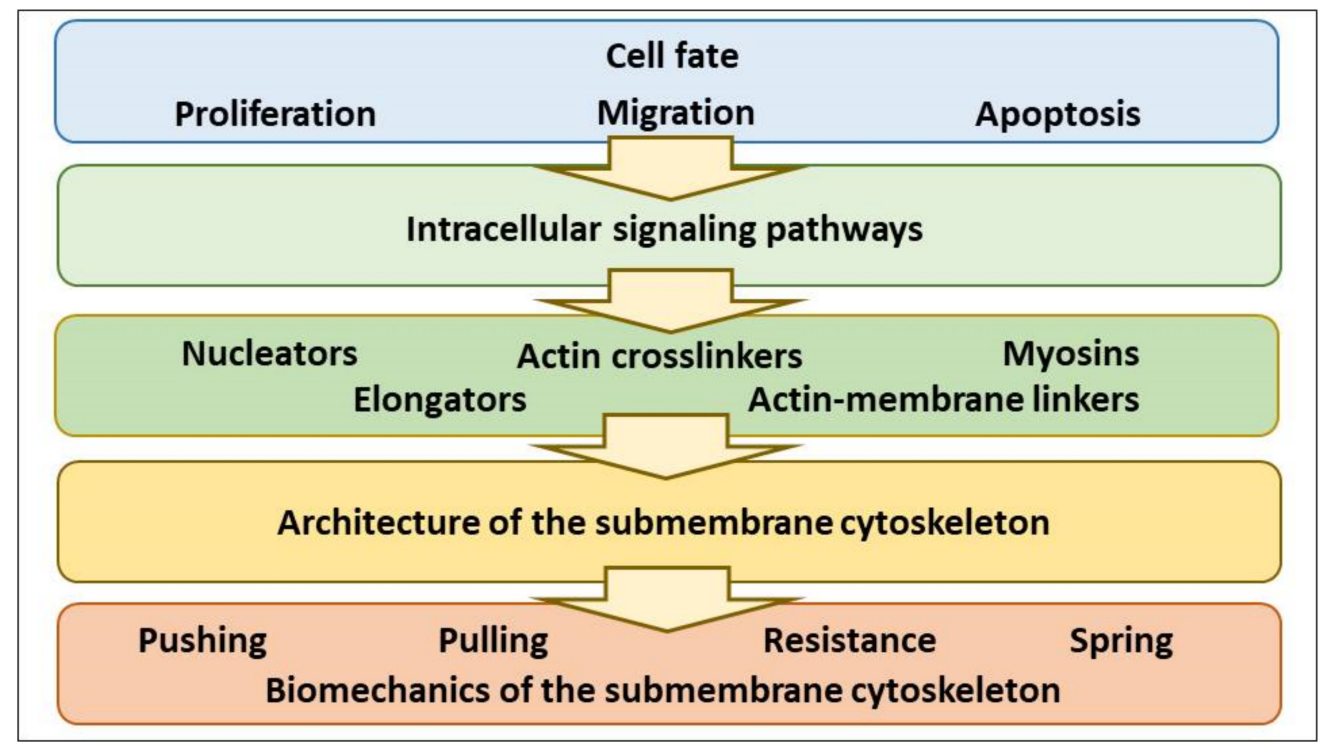

Figure 1. The schematizing of signal transduction from the cell fate-controlling stimuli onto the biomechanics of the PM-smACSK complex.

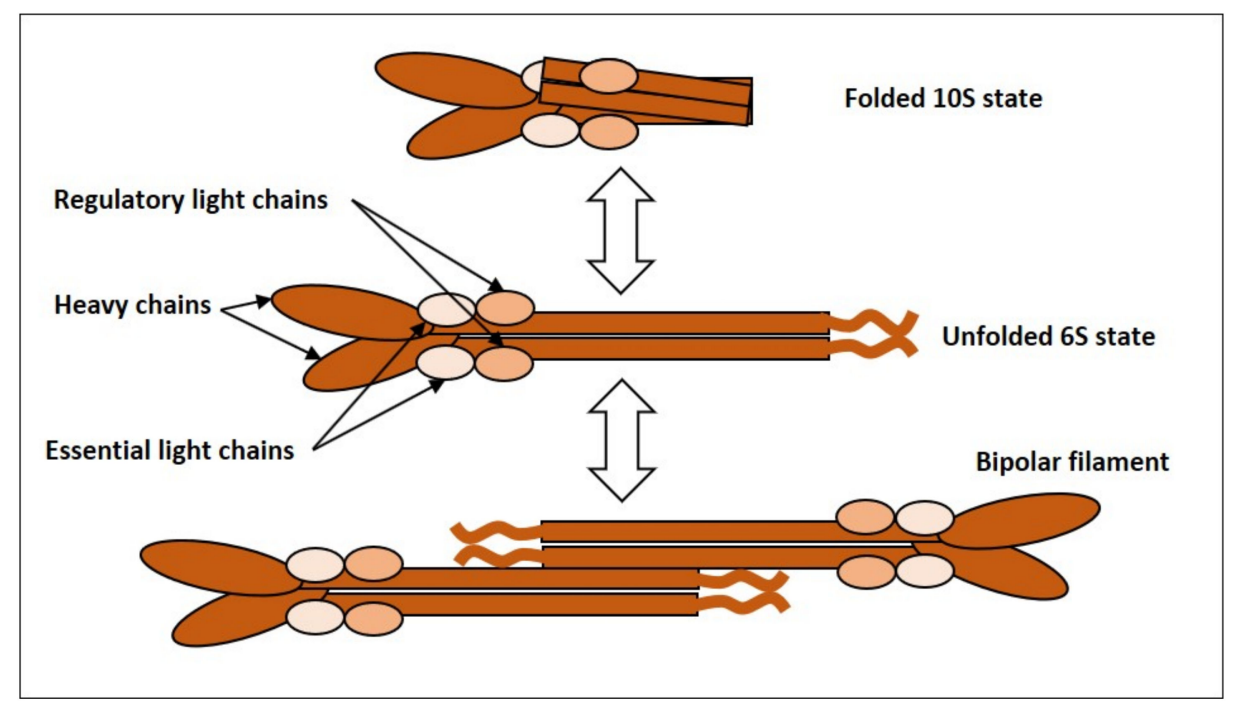

Figure 2. NMMII monomer refers to the heterohexameric complex composed of 2 heavy chains, 2 essential light chains and 2 regulatory light chains. NMMII can exist in a folded assembly-incompetent $10 \mathrm{~S}$ state (top), and an unfolded assembly-competent 6S state (middle). The 6S NMMII can assemble into bipolar filaments (bottom).

The actin-activated ATPase activity of the NMMII heavy chain is stimulated by phosphorylation of Ser19/Thr18 of RLC by $\mathrm{Ca}^{2+}$ / calmodulin-dependent MLCK [20]. Myosin light chain phosphatase (MLCP), where serine/threonine phosphatase 1 (PP1) acts as catalytic subunit, inhibits NMMII via dephosphorylation of Ser19/Thr18 in RLC [21-23]. The small GTPase RhoA stimulates its target ROCK (Rho-associated coiled-coil containing kinase) which activates NMMII contractility both via phosphorylation of Ser19/Thr18 of RLC [24] and phosphorylation and inhibition of MLCP [25]. MLCK can be inhibited 
via phosphorylation by p21-activated kinase (PAK) [26]. In PC12 and N1E-115 cells, Rac1 was shown to induce phosphorylation and inhibition of NMMII in PAK1-independent, $\mathrm{Ca}^{2+}$-dependent manner [27]. Phosphorylation/dephosphorylation of heavy chains of NMMII also control behavior of NMMII [17].

\subsubsection{Evidence for Oscillatory Activity of NMMII}

Sensing and regulation of cell volume is of critical importance for cell survival or induction of proliferation, apoptosis or migration. We suggest that NMMII is constantly measuring the gradient of HP across the elastic PM-smACSK complex. A possible role for NMMII in measuring of $\mathrm{HP}_{\text {in }}$ (intracellular $\mathrm{HP}$ ) and $\mathrm{HP}_{\text {out }}$ (extracellular $\mathrm{HP}$ ) would be repetitive cycles of NMMII activity: contraction of NMMII followed by relaxation as it is described in Section 3. It is therefore of interest to ascertain whether oscillatory activity of NMMII takes place in cells. In mouse embryonic fibroblasts oscillatory activity of NMMII localized at the lamellipodium participates in formation of integrin-mediated adhesion sites [28]. In a number of cell types, mouse embryonic fibroblasts, human breast adenocarcinoma MCF-7 cells and human osteosarcoma U2OS cells, the dynamics of NMMII activity were studied [29]. The authors revealed a localized pulsatile activity of the NMMIIA isoform, while NMMIIB did not show pulsing behavior [29]. The oscillatory activity of NMMIIA was dependent on $\mathrm{Ca}^{2+}$ influx and the activation of MLCK [29].

\subsubsection{Can NMMII Reset Its Own Oscillatory Activity?}

It would be important to understand whether the oscillatory activity of NMMII (discussed above) can be driven by NMMII itself. The RhoA/ROCK module can activate NMMII [24,25], while Rac1/Pak can inhibit it [26,27] (Figure 3). RhoA and Rac1 are themselves under the control of guanine nucleotide exchange factors (GEFs) [30]. All GEFs possess two tandem domains in their catalytic core: $\mathrm{DH}$ [Dbl (diffuse B-cell lymphoma) homology] domain and a PH (pleckstrin homology) domain. The largest family of GEFs is the Dbl family [30-32]. NMMIIA and NMMIIB directly bind to multiple GEFs of the Dbl family: Trio, GEF-H1, FGD1, Kalirin, $\beta$ PIX, LARG, Dbl, Tiam1, Vav1 [33]. DH-PH domains of Dbl family GEFs interact with the head domain of NMMIIB [33]. Assembly of NMMII into filaments and ATPase activity are required for binding to Dbl GEFs. When bound to NMMII, GEFs are inactive. NMMII inhibition with blebbistatin released Dbl GEFs from NMMII and resulted in their reactivation [33]. $\beta$ PIX is a Rac1/Cdc42 specific GEF [33] and its activation may activate Rac1-PAK axis [34] that can inhibit NMMII [26,27]. Surprisingly, when inhibited, NMMII releases and activates $\beta$ PIX and other Dbl family GEFs [33], that might further inhibit NMMII activity (Figure 3). In case of release of active RhoA-specific GEF-H1 from NMMII [33] one may expect activation of the RhoA/ROCK axis and activation of NMMII that would complete the self-supporting cycling activity of NMMII (Figure 3). However, experimental data show dissociation of GEF-H1 from NMMII, but not activation of GEF-H1 [33]. In addition, Rac can downregulate Rho [35,36]. GEF interacting with NMMIIA was identified in HeLa cells and termed MyoGEF (myosininteracting GEF) [37]. MyoGEF is inactive when bound to NMMIIA and is activated upon release from NMMIIA; MyoGEF activates RhoA but not Rac1 [37].

Thus, active NMMII is likely to inhibit its own activity via the $\beta$ PIX-Rac1-PAK pathway [33]. Though the state of NMMII ATPase activity was not determined, NMMII could also activate NMMII itself via the MyoGEF-RhoA-ROCK pathway [37].

In summary, the experimental data are not conclusive to underpin the proposed selfsupporting oscillatory model for NMMII (Figure 3). Alternatively, NMMIIA can drive deformations of the PM, opening of mechanosensitive $\mathrm{Ca}^{2+}$-permeable cation channels, $\mathrm{Ca}^{2+}$ influx, activation of MLCK and stimulation of NMMIIA [29].

\subsection{A Viscoelactic Solid Composed of the PM and the smACSK, a Pushing Motor, a Resistive Force and a Spring}

We consider here the three mechanical properties of the PM-smACSK: as a pushing motor, as a resistance to pushing/pulling and as a spring. However, all four mechanical 
parameters, NMMII is also a constituent of the smACSK, are characterizing the same viscoelastic solid composed of hundreds of proteins that hinders clear distinction of mechanism of generation of any one force.

\subsubsection{The PM-smACSK Complex, Common Features}

Here we define the PM as a lipid bilayer with transmembrane proteins. The lipid bilayer as a solid can be characterized by four elasticity moduli: a compressibility modulus, an area expansion modulus, a bending modulus and an elastic shear modulus [38]. Inclusions, e.g., eicosapentaenoic acid and docosahexaenoic acid, in the lipid bilayer can change its elasticity [39]. The presence of molecular dioxygen in the lipid bilayer is also likely to influence its mechanical properties and the activities of transmembrane signaling proteins [40].

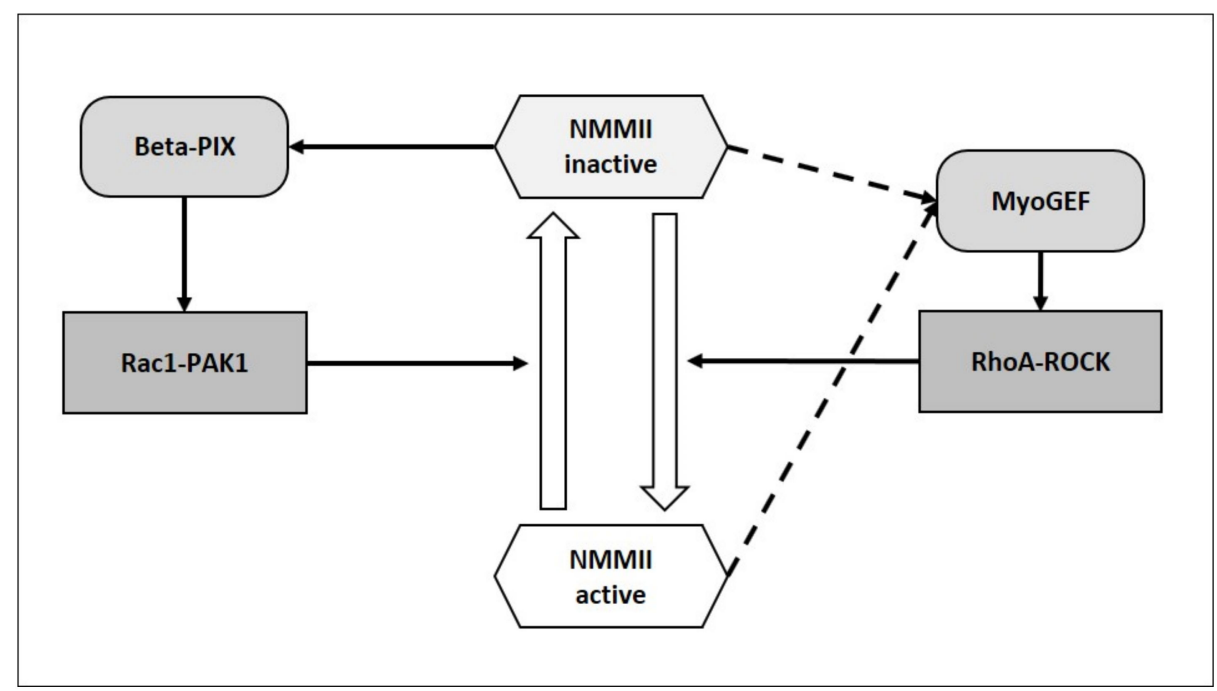

Figure 3. NMMII might induce positive feedback loops. When ATPase activity of NMMII is inhibited, it can release GEFs of the Dbl family, which are likely to further inhibit NMMII via activation of the Rac1-PAK pathway. It is not clear which state of NMMII (active or inactive ATPase activity) can induce the release of active MyoGEF. Active MyoGEF can stimulate NMMII via activation of ROCK.

Underlining the PM is the smACSK composed mainly of spectrin and actin filaments [41,42]. The spectrin-F-actin cytoskeleton is particularly well studied in red blood cells $[43,44]$. Auxiliary proteins such as ankyrin, protein $4.1 \mathrm{R}$, adducin, dematin, tropomyosin and tropomodulin provide "vertical" (between the lipid bilayer and smACSK, directed perpendicularly to the plane of the PM) and "horizontal" (between the constituents of the smACSK, directed tangentially to the plane of the PM) linkages [43,44]. Ankyrin is mainly responsible for connection of Band 3 (anion exchanger 1) with the spectrin-F-actin network, while protein 4.1R brings together glycophorin $C$ and submembrane CSK $[43,44]$. The phosphorylation status of Band 3 influences the erythrocyte deformability [45-49].

In addition, proteins of the plakin family link three major constituents of the CSK F-actin, microtubules and intermediate filaments together [50]. In particular, microtubule actin crosslinking factor 1 [MACF1, also known as actin crosslinking family 7 (ACF7)] integrates actin filaments and microtubules [51]. This MACF1 mediated connection between F-actin and microtubules may serve for signal transduction onto and from microtubules for which we have recently hypothesized a role in the integration of intracellular signaling events [52].

\subsubsection{Protrusive F-Actin Polymerization, a Pushing Motor}

Actin polymerization drives cell motility and migration [53-55]. We propose that the pushing force generated by protrusive actin filaments [54] would probe the strength of $\mathrm{HP}_{\text {out }}$ that drives the PM-smACSK into the cell in case of cell shrinkage. Assembly of 
protrusive F-actin may occur as formation of filopodia, finger-like protrusions with parallel actin bundles, or lamellipodia, flat protrusions formed by branched actin filaments [54].

\subsubsection{A Resistive Force Generated by the PM-smACSK}

When the PM-smACSK complex is being pulled into cell by NMMII, the NMMII contractility is to overcome the rigidity of the PM-smACSK. The rigidity of the PM-smACSK is mainly determined by elasticity of proteins comprising the smACSK and by the strength and number of "vertical" and "horizontal" links between the constituents of the PMsmACSK. The force acting against movement of the PM out from cell is referred to as membrane tension, a complex parameter including the in-plane tension in the lipid bilayer and the energy of adhesion between the PM and the smACSK [56]. However, in fish keratocytes the force generated by actin protrusions can increase membrane tension [56].

\subsubsection{Spring-Like Behavior of the PM-smACSK}

According to our hypothesis the complex composed of the PM with tightly bound smACSK undergoes NMMII- and F-actin-driven cycles of displacements in directions normal to the lipid bilayer (Figure 4). Deformation of the lipid bilayer and the underlining CSK can vary from completely elastic deformation (Figure 4, upper panel) to completely plastic deformation (Figure 4, lower panel). In the case of elastic deformation, the PMsmACSK completely recovers its shape, while in the case of plastic deformation the PMsmACSK retains change in its form (Figure 4).

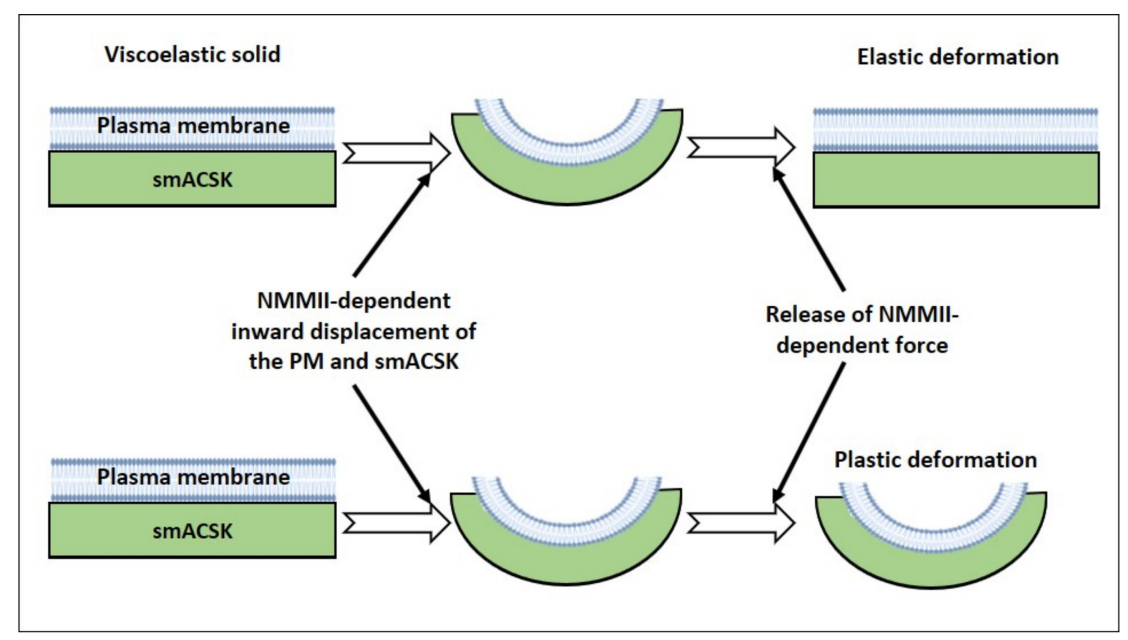

Figure 4. Illustration of behavior of a viscoelastic solid composed of the plasma membrane (blue rectangle) and the underlining submembrane cytoskeleton (green rectangle). Upper panel: in case of elastic deformation of the PM-smACSK under NMMII-generated pulling force the PM-smACSK completely restores its shape after the relaxation of NMMII. Lower panel: in case of the plastic deformation of the PM-smACSK, the PM-smACSK retains its deformed shape even after relaxation of NMMII.

\subsection{Cell Fates Requiring Volume Change}

\subsubsection{Proliferation}

Cell proliferation requires a shift in the cell volume set point to a greater cell volume [1,2]. In our hypothesis cell program-dependent changes in four mechanisms are necessary for adjustment of the volume set point: NMMII activity, F-actin protrusions, resistive and elastic behavior of the PM-smACSK complex. EGF can trigger both proliferation and migration [57-59], but the mechanism discriminating between EGF-induced proliferation and migration yet remains elusive. The EGF receptor family comprises four members ErbB1/HER1, ErbB2/HER2/Neu, ErbB3/HER3 and ErbB4/HER4 [59]. The three main signaling pathways activated by EGF are Ras-Raf-MEK1/2-ERK1/2, Akt-PI3K-mTOR and PLC- $\gamma 1-P K C$ [59]. Ras, a family member of the small GTPases downstream of growth 
factor receptors [60], via Rho-ROCK pathway may thus control both NMMII [61] and actin CSK $[62,63]$.

In a kidney proximal tubule epithelial LLC-PK1 cell line and a canine distal tubular epithelial MDCKII cell line, EGF activates RhoA via ERK-mediated activation of GEF-H1 [64]. In COS-7 cells, EGF was shown to activate ERK which further phosphorylated RhoA at Ser-88 and Thr-100 that enhanced RhoA activity, increased interaction between RhoA and its target ROCK1, ROCK1 phosphorylated MYPT1 [58]. EGF-induced ERK-mediated RhoA phosphorylation increased stress fiber formation [58]. In COS-7 cells, EGF was shown to activate Rac1 [57]. In COS-7 cells EGF activated ERK and ERK phosphorylated Rac1 at Thr-108 that decreased Rac1 activity and targeted Rac1 to the nucleus [57].

Since we propose that EGF tunes mechanosensitive mechanisms in the cell, the recent observation on fine-tuning of mechanics of integrin by EGF is of interest [65]. In Cos-7 cells, EGF attenuates the threshold of integrin tension generation and increases focal adhesion assembly and cell spreading [65].

GPCRs are among key drivers of cancer cell growth [66], they are also involved in cell volume regulation [67]. Via $\beta$-arrestins and small GTPases, GPCRs can regulate filamin-A, cortactin, cofilin and thus regulate re-arrangements of the CSK that contribute to cancer cell survival and proliferation [66]. In the context of our hypothesis GPCR - the $\beta$-arrestin axis via effects on the CSK [66] may regulate both rigidity of the CSK and its spring-like behavior, i.e., the ability of the submembrane spectrin-F-actin CSK to store energy of deformation.

\subsubsection{Migration}

Migration of a single cell on a 2D substrate can be divided into two modes: mesenchymal and ameboid [68]. Mesenchymal migration occurs via 5 successive steps: (1) formation membrane protrusions at the leading edge; (2) assembly of focal adhesions; (3) proteolysis of the extracellular matrix by cell surface proteases; (4) translocation of the cell body; and (5) retraction of the rear of the cell [69]. Localized swelling and shrinkage take place at the leading edge and trailing edge, respectively, that requires concerted work of multiple ion channels and transporters [70]. In our model, re-modeling of both submembrane CSK and changes in activities of NMMII would tune volume set points, that appear to be different at the front and the rear of the migrating cell.

A number of signaling proteins regulate cell migration including the small GTPases Rho, Cdc42 and Rac [62,71,72]. The Rho-ROCK axis governs both NMMII activity [24,25] and actin-based CSK architecture [62,71,72]. In the prostate carcinoma TSU-pr1 cell line, EGF can induce chemotaxis and was shown to regulate NMMIIA and NMMIIB heavy chain phosphorylation by PKC [73]. It should be noted that in migrating cells, NMMIIA and NMMIIB seem to be regulated in distinct modes [73] and to be asymmetrically redistributed [74-76]. NMMIIA was shown to move to the leading edge, while NMMIIB was shown to accumulate at the rear of the cell [74-76]. It appears that the C-terminal tails of heavy chains of NMMIIA and NMMIIB determine differential distribution of these isoforms in migrating cells [76]. Moreover, in addition to their motor activities, NMMIIA and NMMIIB can participate in the control of membrane protrusion formation and dynamics of focal adhesions [77].

\subsubsection{Apoptosis}

Execution of apoptosis depends on a decrease in cell volume, that was termed apoptotic volume decrease (AVD) [6,8]. In our hypothesis, AVD may be linked to a NMMII- and PM-smACSK-dependent shift in volume set point, since signaling pathways mediating cell death can also control NMMII. In PC12 cells and cultured rat cortical neurons oxidative stress-induced apoptosis involves sequential activation of caspase-3, ROCK1 and myosin light chain (MLC) that leads to NMMIIA activation [78]. Inhibition of NMMIIA with blebbistatin was shown to suppress cell death in human red blood cells [79], in neurons [78], in hair cell-like HEI-OC-1 cells and in cochlear hair cells [80]. 
Voltage-dependent anion-selective channel 1 (VDAC1), originally described as a mitochondrial outer membrane protein [81], is also expressed in the plasma membrane [82], where it enriches in caveolae [83] and lipid rafts [84] and has been implicated in cell volume control [85]. VDAC1 is known to directly bind to actin [86,87]. In neuronal cells, opening of plasma membrane VDAC1 channels was described to precede caspase activation and antibodies against VDAC1 were able to prevent apoptosis in these cells [88].

\section{3. "Two Motors and One Spring" Model}

Our two motors and one spring model consists of three core elements: NMMII, as a pulling motor, F-actin-based protrusions as a pushing motor, and PM-smACSK as a spring. These three elements can act together in measuring the strength of the hydrostatic pressure that does not displace the PM-smACSK under normal cell volume (Figure 5A) but drives inward displacements of the PM-smACSK during cell shrinkage (Figure 5B) and outward displacements during swelling (Figure 5C). It should be mentioned that the plasma membrane in living cells is ever undergoing the excursions in directions perpendicular to the plane of the membrane, the phenomenon known as cell membrane fluctuations $[55,56]$. It would be tempting to assume that NMMII drives cell membrane fluctuations, however, at least in human red blood cells, NMMII was shown not to contribute to membrane fluctuations [57].

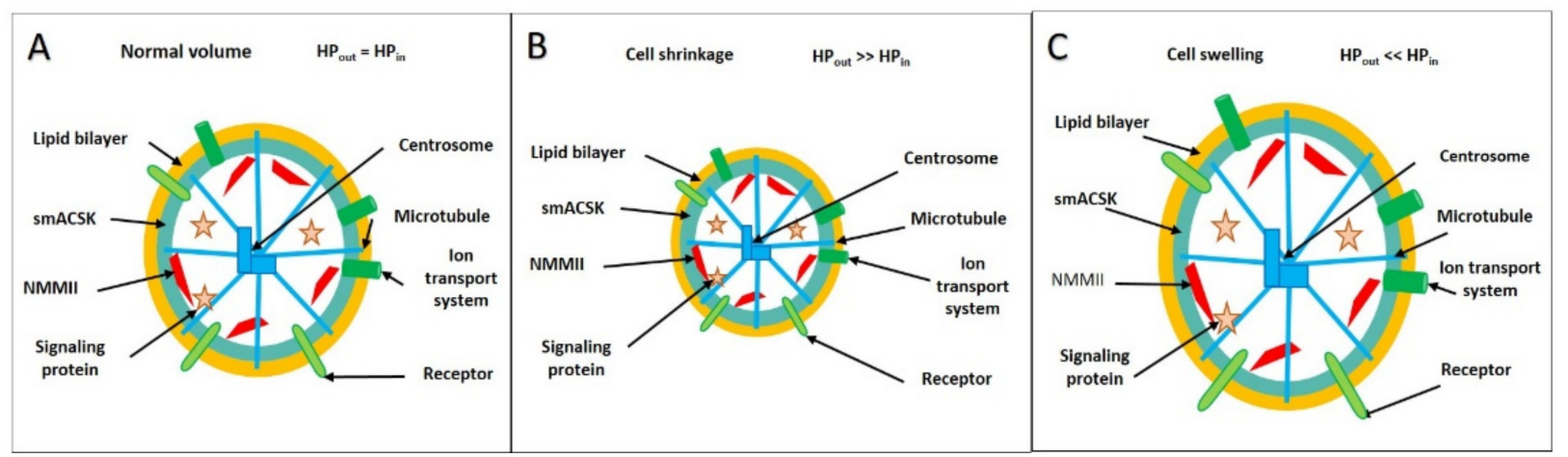

Figure 5. (A-C). Key players of cell volume sensing and regulation are NMMII (red dashes), the PM (yellow circle) together with the smACSK (blue-green circle) form the PM-smACSK complex, signaling proteins (red asters), cell surface receptors (green ovals) and ion transport systems (dark-green figures). The centrosome-based microtubular CSK (blue figures) forms the bulk CSK. Under normal cell volume, there is an equilibrium of hydrostatic pressure in the cell $\left(\mathrm{HP}_{\text {in }}\right)$ and in the surrounding milieu ( $\left.\mathrm{HP}_{\text {out }}\right)$ so that the shape of any local patch of the PM-smACSK can be assumed as planar (A). Under cell shrinkage, the PM-smACSK is being pulled into the cell (B). Under cell swelling, the PM-smACSK is being pushed into the extracellular space $(\mathbf{C})$.

When a cell is in an isosmotic milieu the intracellular hydrostatic pressure $\left(\mathrm{HP}_{\text {in }}\right)$ is equal to the extracellular hydrostatic pressure $\left(\mathrm{HP}_{\text {out }}\right)$ (Figure $\left.5 \mathrm{~A}\right)$. Exposure of a cell to a hyperosmotic solution induces an efflux of water resulting in an increase of the hydrostatic pressure in the surrounding milieu, $\mathrm{HP}_{\text {out }}$, and cellular compression: the cell shrinks (Figure 5B). Exposure of the cell to an hypoosmotic solution induces influx of water resulting in an increase of the intracellular $\mathrm{HP}_{\text {in }}$ and inflation of the cell: the cell swells (Figure 5C).

PR65, a scaffolding subunit of protein phosphatase 2A (PP2A), possesses a HEATrepeat (Huntingtin, elongation factor 3, a subunit of protein phosphatase 2, PI3 kinase target of rapamycin 1) [89]. Studies of the elastic behavior of the HEAT-repeat protein PR65 show that extension of PR65 opens the substrate/catalysis interface and activate PP2A, while compression of PR65 closes the substrate/catalysis interface and inhibits PP2A [89]. Thus, PR65 can link mechanical stress sensing and activation/inhibition of the signaling protein PP2A. In Calu-3 airway, epithelial cells F-actin serves as a scaffold for bringing together NKCC1 and its regulators such as protein kinase C- $\delta$ (PKC- $\delta$ ), STE20-related 
proline-alanine-rich kinase (SPAK) and PP2A [90]. PP2A dephosphorylates and inhibits NKCC1 with which was co-immunoprecipitated from Calu-3 cell lysates [90]. In addition, PP2A can dephosphorylate and activate the KCC [91].

Considering the behavior of any mechanosensitive transmembrane or membraneassociated protein, e.g., PP2A [89], under cell shrinkage and swelling in an oversimplified approximation (Figure 6). For a mechanosensitive protein to be activated/inhibited by mechanical stress it needs to be fixed at least at two points, e.g., at the plasma membrane and the bulk microtubule-based CSK (Figure 6A). We assume the bulk microtubule-based CSK as being immobile during cell volume changes that allows us to use it as a reference point for the assessment of the PM-smACSK displacement and of degrees of compression/distension of any single protein in radial direction (Figure $6 \mathrm{~B})$. The same compressive force $\left(\mathrm{HP}_{\text {out }}\right)$ that changes membrane curvature under cell shrinkage would compress any mechanosensitive protein in the cell, while increase in $\mathrm{HP}_{\text {in }}$ during cell swelling would distend it (Figure 6C).

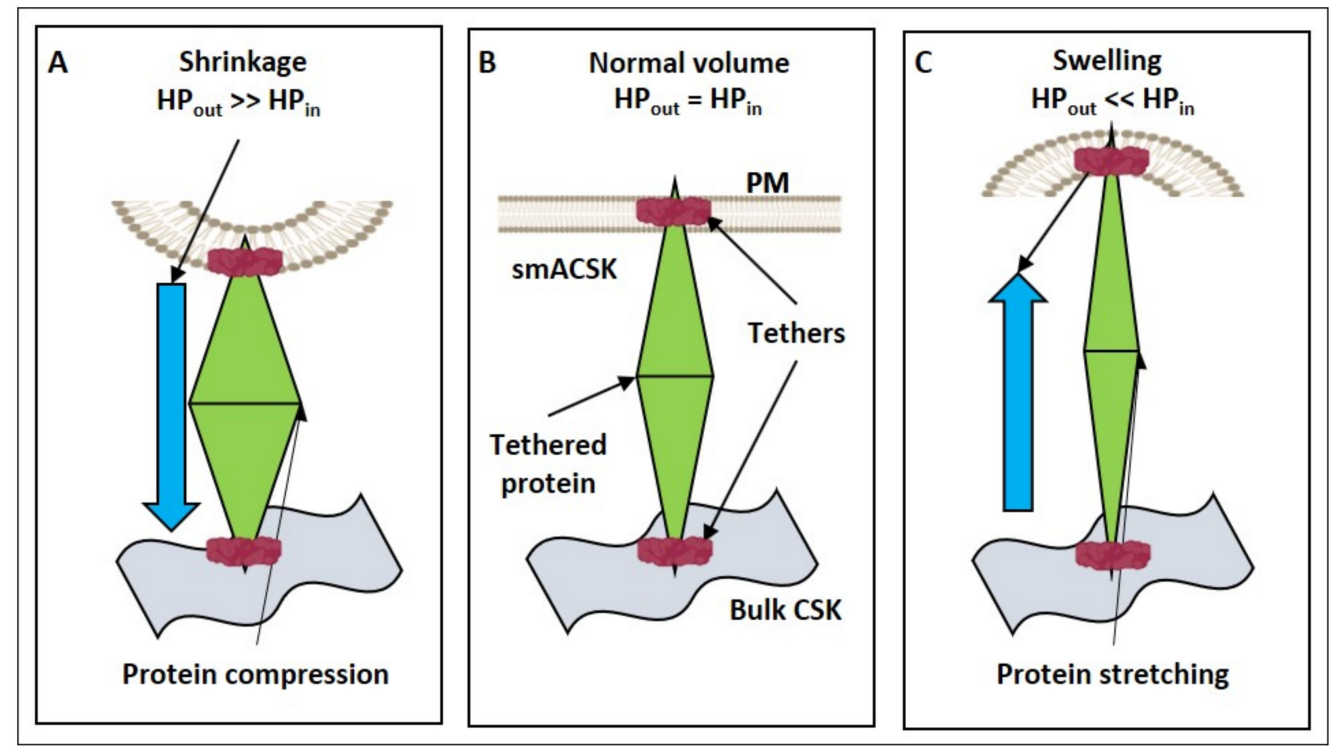

Figure 6. A transmembrane protein or membrane-associated protein (green diamond) is fixed by tethers (red ovals) at the PM-smACSK (orange and blue-green figures) and at the bulk CSK (grey wavy figure). (A): A mechanosensitive protein undergoes compression during cell shrinkage. (B): A mechanosensitive protein in normal cell volume. (C): A mechanosensitive protein undergoes stretching during cell swelling.

If one excises any small patch of the PM-smACSK from a cell with normal volume, then this patch can be regarded as planar (Figures 6 and 7). In our model any local planar patch of the PM-smACSK (i) undergoes NMMII-dependent outward excursion, (ii) then NMMII relaxes and the PM-smACSK spring returns the PM-smACSK into planar shape, (iii) activation of NMMII pulls the PM-smACSK into the cell, and (iv) relaxation of NMMII and the PM-smACSK spring returns the PM-smACSK in planar shape (Figure 7). Signal transduction from NMMII and F-actin onto signaling proteins is discussed in Section 5.

\subsection{Hyperosmolarity-Driven Inward Movement of the PM-smACSK versus F-Actin-Driven Outward Movement of the PM-smACSK: Sensing of Cell Shrinkage}

Assuming that in order to detect the increase in $\mathrm{HP}_{\text {out }}$-that pushes the PM-smACSK into the cell interior-the cell would generate a force that drives the PM-smACSK in the opposite direction (Figure 7A-C). In our model, PP2A is tethered to both PM and smACSK (Figure 8). Cell shrinkage compresses and inactivates PP2A as observation on PP2A mechanosensitivity allows to suggest [89] (Figure 9). This inhibition of PP2A leads to phosphorylation and activation of NKCC1 [90] and to phosphorylation of KCC that inhibits KCC during shrinkage [91] (Figure 9). 


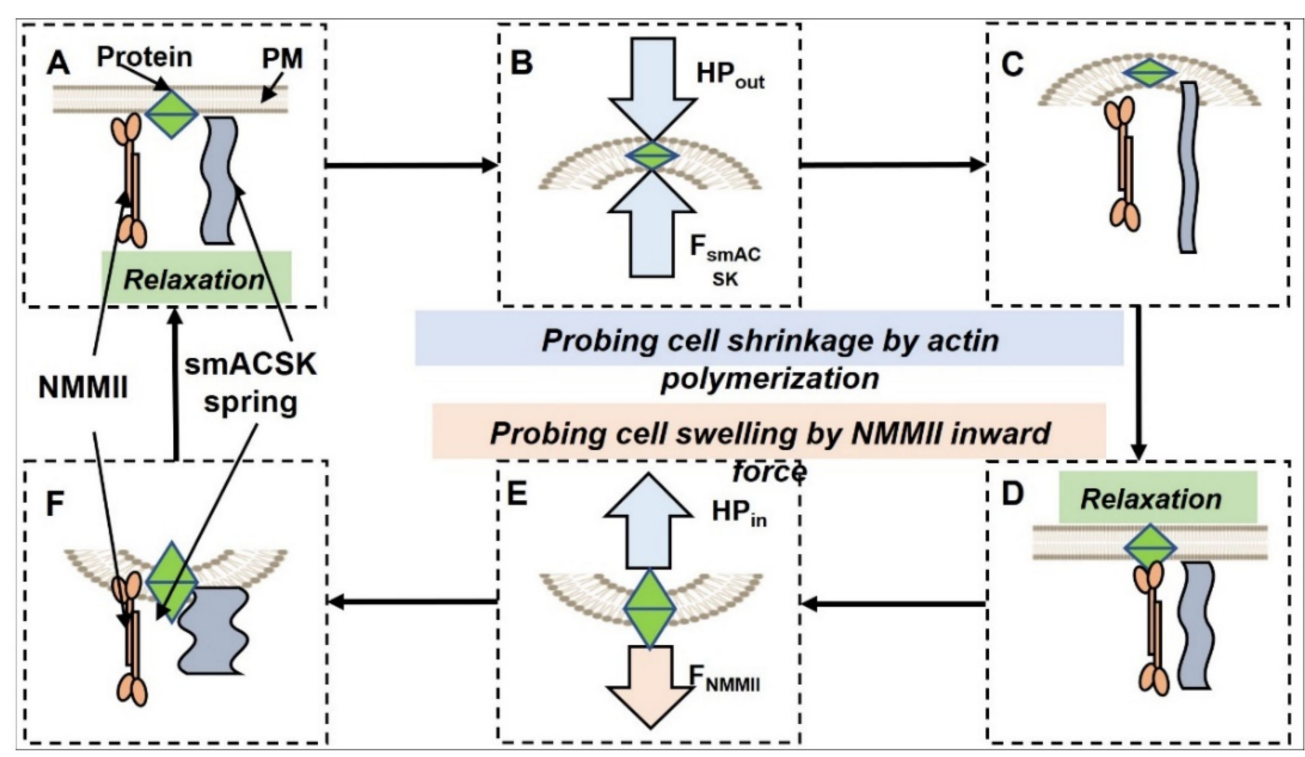

Figure 7. Scheme illustrating "two motors-one spring" model for probing of forces that drive displacements of the PM-smACSK out from or into the cell. (A-C): a force of F-actin protrusion drives the PM-smACSK out of the cell in order to probe the $\mathrm{HP}_{\text {out }}$ that in case of cell shrinkage drives the PM-smACSK into the cell. (B): A mechanosensitive signaling protein (green diamond) experiences compression that either activates or inhibits it. (C,D): After depolymerization of the protrusive actin filaments, the PM-smACSK restores its planar shape. (D-F): NMMII pulls the PM-smACSK into the cell and thus probes the increase in $\mathrm{HP}_{\text {in }}$ in case of cell swelling. (E): A mechanosensitive protein experiences distention that either activates or inhibits it. (F-A): NMMII is relaxed and the PM-smACSK spring restores its planar shape.

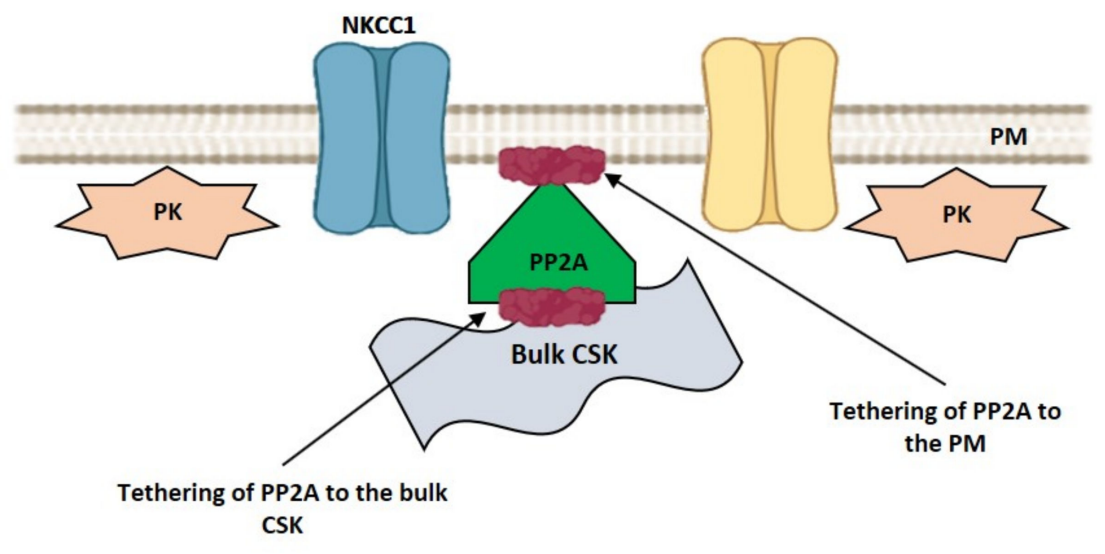

Figure 8. At normal cell volume NKCC1 and KCC are inactive, and their phosphorylation by proteins kinases and dephosphorylation by PP2A are balanced.

\subsection{Relaxation of Both F-Actin-Driven Force and the PM-smACSK Spring}

We presume the PM-smACSK is an elastic solid assuming dome-like shape under NMMII-dependent excursion of the PM-smACSK. Being an elastic solid the PM-smACSK stores energy of deformation and, as soon as NMMII is inactive, the elastic PM-smACSK returns to its planar shape (Figure 7C,D). Also, this relieve of PM-smACSK tension returns the PP2A to its normal state. 


\subsection{Hyposmolarity-Driven Outward Movement of the PM-smACSK versus NMMII-Driven} Inward Movement of the PM-smACSK: Sensing of Cell Swelling

The next step in this hypothetical cycle of NMMII activity is the activation of NMMII and pulling the PM-smACSK into the cell against the increased $\mathrm{HP}_{\text {in }}$ that drives the PM-smACSK out of the cell in case of cell swelling (Figure 7D-F).

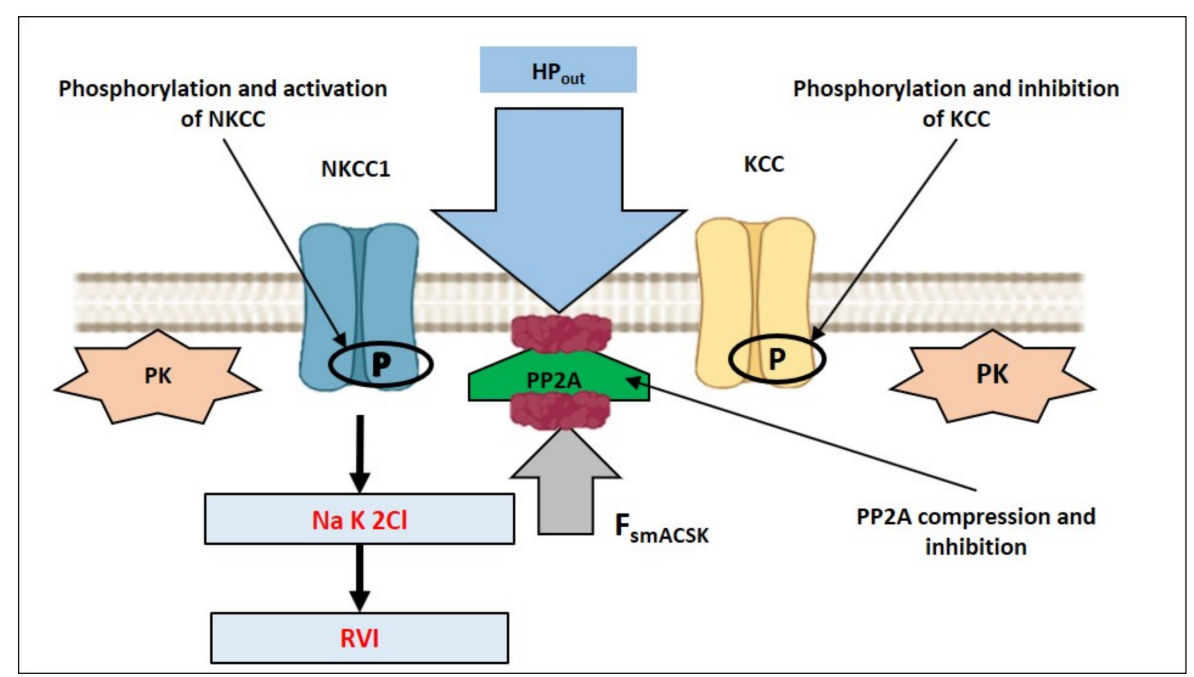

Figure 9. Illustration of hypothetical inactivation of mechanosensitive PP2A during cell shrinkage. PP2A can be compressed by both $\mathrm{HP}_{\text {out }}$ and $\mathrm{F}_{\text {smACSK }}$ and thus inactivated. Inactivation of PP2A would increase phosphorylation of NKCC1 by PKs that would activate NKCC1 and lead to RVI. In addition, phosphorylation of KCC by PKs would inactivate it.

In our model, cell swelling extends and thus activates PP2A as the study of PP2A mechanosensitivity suggests [89] (Figure 10). Activation of PP2A leads to dephosphorylation and inactivation of NKCC1 [90] and to dephosphorylation and activation of KCC [91] during cell swelling (Figure 10). Some other connections between NMMII and signaling proteins, involved in RVD, are discussed in Section 5.

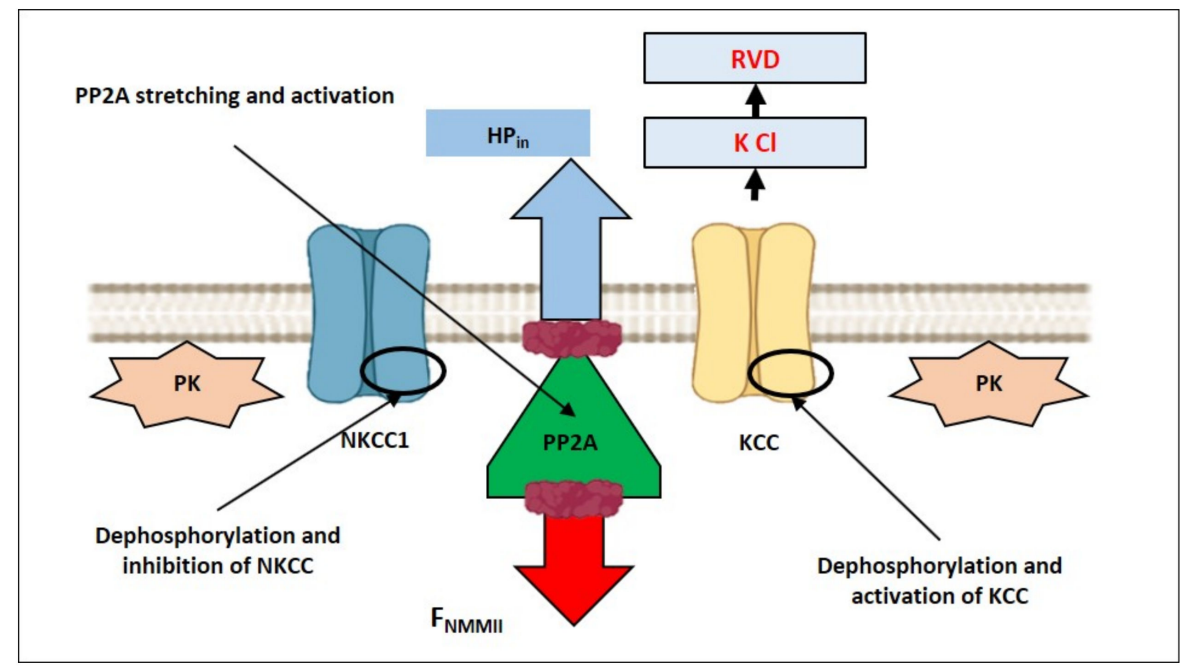

Figure 10. Illustration of hypothetical activation of mechanosensitive PP2A during cell swelling. During cell swelling PP2A can be stretched by $\mathrm{HP}_{\text {in }}$ and $\mathrm{F}_{\mathrm{NMMII}}$ and thus activated. KCC would be activated by dephosphorylation by PP2A and would lead to RVD. In addition, dephosphorylation by PP2A would inhibit NKCC1. 


\subsection{Relaxation of the Both NMMII and the PM-smACSK Spring}

Inward displacement of the PM-smACSK, that is transition of the PM-smACSK from planar to dome-like shape, results in an accumulation of energy of deformation in the PM-smACSK. Relaxation of NMMII relieves a force acting on the PM-smACSK and the PM-smACSK returns from dome-like into planar shape (Figure 7F). Thus, one hypothetical cycle of concerted work of NMMII and PM-smACSK spring is completed and the next cycle of NMMII and PM-smACSK spring dynamics can begin (Figure 7).

\section{How Can NMMII, and the PM-smACSK Complex Sense Intracellular Ionic Strength?}

Salt bridges and hydrogen bonds between oppositely charged residues may underlie sensing of intracellular ionic strength by NMMII and F-actin protrusions.

Non-muscle myosin was identified in human erythrocytes [92]. Later on, human erythrocytes were shown to express the NMMIIA isoform [93]. ATPase activity of human erythrocyte NMMII is very low at low ionic strength $(0.06 \mathrm{M} \mathrm{KCl})$ in the presence of EDTA, a calcium chelator, or in the presence of $\mathrm{MgCl}_{2}$ [92]. Moreover, NMMII appears to distinguish between $\mathrm{Na}^{+}$and $\mathrm{K}^{+}$cations, since ATPase activity of NMMII in the presence of $2 \mathrm{mM}$ EDTA was reported as $0.376 \mu \mathrm{mol} / \mathrm{min}$ per $\mathrm{mg}$ in $0.5 \mathrm{M} \mathrm{KCl}$, but as $0.118 \mu \mathrm{mol} / \mathrm{min}$ per $\mathrm{mg}$ in $0.5 \mathrm{M} \mathrm{NaCl}$ [92]. Similarly, the ATPase activity of NMMII in the presence of $10 \mathrm{mM} \mathrm{CaCl}_{2}$ was about 2-fold higher $(0.478 \mu \mathrm{mol} / \mathrm{min}$ per $\mathrm{mg})$ in $0.5 \mathrm{M} \mathrm{KCl}$ than in $0.5 \mathrm{M} \mathrm{NaCl}(0.204 \mu \mathrm{mol} / \mathrm{min}$ per $\mathrm{mg})$ [92]. The presence of negatively and positively charged regions in the coiled-coil rod domains of NMMII $[94,95]$ may be responsible for its sensitivity to ionic strength. F-actin itself is negatively charged and can bind to positively charged lipids [96]. Numerous proteins that provide assembly of the actin CSK possess negatively and positively charged domains involved in protein-protein interactions. Palladin, an actin cross-linking protein, possesses two basic sequences on opposite sites of an immunoglobulin 3 domain which provide electrostatic interaction of paladin with two actin filaments [97].

Negatively charged G-actin and F-actin can bind to positively charged lipids [96]. Positively charged pleckstrin homology $(\mathrm{PH})$ domain in various adaptor and signaling proteins provide binding of these proteins to negatively charged phosphoinositides [98].

\section{NMMII Can Directly Interact with and Modulate Activities of Transmembrane Mechanosensors of the PM}

\subsection{Anionic Lipids}

Pulling or pushing of the lipids of the PM can generate mechanical pressure in the lipid bilayer that would be sensed by transmembrane mechanosensors [38,99,100]. Actin CSK can interact with the membrane phosphoinositides via PH domains of adaptor proteins [98,101].

C-terminal fragments of heavy chains of NMMII bind directly to phosphatidylserine (PS) lipid vesicles and liposomes [102-105] and this binding is independent of F-actin [105]. It was demonstrated that $\mathrm{N}$-terminal myosin heads could also interact with membrane phosphatidylserines [105]. Interestingly, binding of NMMII to acidic liposomes leads to displacement of RLCs from the myosin heavy chains [105] and an excess of RLCs suppressed its binding to phosphatidylserine vesicles suggesting phosphorylation of RLCs may regulate the interaction of NMMII to PS and downstream signaling. In Drosophila neural stem cells NMMII RLC, Sqh (Spaghetti-squash), binds to a number of phosphoinositides: a phosphatidylinositol 4-phosphate [PtdIns(4)P], phosphatidylinositol 3,4-bisphosphate [PtdIns(4,5)P2], phosphatidylinositol 3,4,5-trisphosphate [PtdIns $(3,4,5) \mathrm{P} 3]$, phosphatidylethanolamine, and is anchored to cell cortex by phosphatidylinositol transfer protein Vibrator [106]. This sqh, PIs, and vibrator complex regulates asymmetric cell division.

\subsection{Ion Channels}

Ion channels are pore-forming membrane proteins located in cellular membranes and allow the passage of ions through the channel pore [107]. NMMII seems to interact with several membrane localized ion channels where it plays important role in channel 
trafficking and spatial localization. For example, in rat embryonic neurons NMMIIB binds to Kv2.1 ion channel via its C- and N-termini and regulates its transport from cytoplasm to membranes [108]. Pharmacological inhibition or knockdown of NMMIIB both suppress Kv2.1 membrane translocation [108]. Likewise, it has been shown that various NMMII isoforms directly interact with $\mathrm{Na}^{+} / \mathrm{K}^{+}$-ATPase $\alpha 1$ subunit and play a role in its transport and trafficking both in neuronal and non-neuronal cells [109]. Furthermore, NMMIIB in neurons interacts with Cav2.1 $\mathrm{Ca}^{2+}$ channel and is involved in its localization to membrane [110]. Alternatively, ion-channel activity may also regulate NMMII activity. For example, in megakaryocytes, TRPM7-mediated $\mathrm{Mg}^{2+}$ homeostasis regulates NMMIIA activity that regulates platelet generation from megakaryocytes [111]. Direct interaction between actin CSK and mechanosensitive ion channels are reviewed elsewhere [38,99].

\subsection{Integrins}

Integrins are heterodimeric adhesion molecules consisting of an $\alpha$ and a $\beta$ subunit and link the intracellular signaling components and actin cytoskeleton to the extracellular matrix. They are structural proteins playing an important role in mechanosensory transduction and they mediate both inside-out and outside-in signaling [112]. Integrins are tethered to the actin CSK via a number of adaptor proteins, e.g., talin, vinculin, $\alpha$-actinin, filamin, tensin, kindlin [112]. Integrins' role as mechanosensors can proceed via three levels: first level, modulation of integrin conformation by mechanical force; second level, mechanosensitivity of the integrin-ligand binding; third level, mechanosensitivity of integrin-linked proteins, e.g., talin [112].

Several lines of evidence suggest that, at least in hepatocytes, they act as volume sensors and are clustered in response to cell volume changes [113-116]. Clustering of integrins in response to volume changes mediates signaling via their cytoplasmic tails to various intracellular pathways leading to activation of ion channels involved in the adjustment of regulatory cell volume [116-120].

Interaction between integrins and NMMII is less studied field. The Stouffer lab first reported accumulation of NMMII heavy chains at alpha $v$ beta 3 integrin complexes in response to vascular injury in smooth muscle cells [121]. Later Rivera Rosado et al. demonstrated a physical interaction between the NMMIIA heavy chain and the alpha 4 integrin tail that plays a role in cell migration [122]. Likewise, the NMMIIA heavy chain is recruited to integrin lymphocyte function-associated antigen (LFA)- 1 where it regulates lymphocyte tail detachment and migration [123]. Focal adhesion kinase (FAK), a nonreceptor protein tyrosine kinase, is involved in both RVI and RVD [2]. FAK can bind to growth factor receptor bound protein 2 (Grb2) [124], while Grb2 appears to directly interact with NMMII [125].

\subsection{G protein Coupled Receptors (GPCRs)}

It is well documented that activation of various GPCRs can influence the activity of NMMII via activation of downstream kinases and phosphatases and thus may play a role in cell-volume regulation [61]. However, data on direct interaction of NMMII and GPCRs is scarce. A recent study has highlighted an interaction between CXCR4 and NMMIIA [126]. CXCR4 is a GPC chemokine receptor that shuttles between the plasma membrane and nucleus [127]. Xu and colleagues have reported that NMMIIA interacts directly with CXCR4 mediating its nuclear translocation and cell migration [126]. In HEK-293 cells actin CSK destabilization with cytochalasin D was shown to influence signal transduction through the serotonin ${ }_{1 \mathrm{~A}}$ receptor [128].

\subsection{Growth Factor Receptors or Receptor Tyrosine Kinases (RTKs)}

There is the surprising observation that epidermal growth factor receptor (EGFR) can be activated by both swelling and shrinkage [129]. Downstream of RTKs are phosphoinositide 3 kinase (PI3K), 3-phosphoinositide-dependent protein kinase-1 (PDK1) and protein kinase B (PKB, also known as Akt) [130]. In Swiss 3 T3 fibroblasts, hyposmolarity activates 
the EGFR/PI3K/Akt axis, resulting in taurine efflux [131]. The muscle isoform of myosin II isolated from rabbit skeletal muscle binds to the pleckstrin homology $(\mathrm{PH})$ domain of PKB [132]. Interaction of the PH domain of PKB with PtdIns (3,4,5)P3 and PtdIns $(4,5) \mathrm{P} 2$ produced by PI3K induces conformational change in PKB making PKB activatable by PDK1 [133]. Questions arise if NMMII can bind to the PH domain of PKB, and if contractile activity of NMMII can influence the PKB conformational change responsible for activation of PKB by PDK1.

Tyrosine-phosphorylated EGFRs and platelet-derived growth factor receptors (PDGFRs) can directly interact with growth factor receptor bound protein 2 (Grb2) which transmits the signal further onto the small GTPase Ras [134]. In NIH3T3 cells Grb2 appears to directly interact with dynamin II [135] and NMMII [125]. Also, dynamin II seems to directly interact with NMMII in NIH3T3 cells [125]. This association of RTKs with NMMII mediated by Grb2 and dynamin II $[125,135]$ might transmit a traction force generated by NMMII onto RTKs and induce their activation under cell swelling. Grb2, which was reported to associate with NMMII [125], can participate in signal transduction from a NMMII generated force onto Ras [134]. Ras itself is involved in activation of mitogen-activated protein kinases (MAPKs) [136], while MAPKs are well known to mediate cell responses to osmotic challenges [2]. Dimerization of the EGFR depends on remodeling of the actin CSK [137].

\subsection{Angiotensin-Converting Enzyme (ACE)}

ACE is a membrane protease expressed in several tissues and an important component of the renin-angiotensin system (RAS). It converts angiotensin (Ang) I to Ang II which regulates blood pressure through its effects on the kidneys, brain, heart and blood vessels. In addition to the cleavage of Ang I to Ang II, ACE has been reported to interact directly with NMMII and participate in outside-in signaling in endothelial cells [138]. Based on these data, we propose ACE may be involved in cell-volume regulation via its direct interaction with NMMII.

\section{Towards the Experimental Testing of the Hypothesis in Live Cell in Real Time}

Experimental testing of our model requires the real-time live-cell observation of the cascade of the following signaling and executive events.

1. Visualization of activation of cell surface receptors-that is observation of signaling that fine-tune the NMMII and smACSK;

2. Visualization of signaling proteins that transmit signal from cell surface receptors onto NMMII and smACSK;

3. Observation of activation of NMMII and re-arrangements of the smACSK;

4. Recording of pulling force and pushing force exerted by NMMII and actin protrusions, respectively;

5. Visualization of activation of transmembrane signaling proteins by NMMII-driven pulling force and actin protrusion-driven pushing force;

6. Observation of activation of signaling proteins that transduce signal from the transmembrane signaling proteins onto ion transport systems;

7. Observation of activation of ion transport systems responsible for RVI and RVD.

In our model cell surface receptors are to be activated twice, when they adjust cell volume point to execution of particular cell program, and when they are activated by mechanical stresses generated by cell swelling, shrinkage and NMMII and protrusive F-actin. Thus, signaling from EGFR is suggested to tune volume sensing machinery (see Section 2.3) and EGFR itself can be activated both by swelling and shrinkage [129]. $<$ EGFR visualization>. Swelling of neuronal cells occurs under pathological conditions such as hyponatremia and hypoxia/ischemia [139]. Neuronal cells respond to swelling via efflux of inorganic and organic osmolytes (Fisher et al., 2008+). Ligand-dependent activation of various GPCRs contributes to stimulation of osmolytes efflux in neuronal cells (Fisher et al., 2008+). Methods for real-time live-cell observations of GPCRs' activation 
are available $[140,141]$. Activation of Gq protein can also be visualized in live cell in real time [142].

Protein tyrosine kinases of the Src family, presented by nine members (Src, Fyn, Yes, Fgr, Blk, Lck, Hck, Lyn and Yrk), participate in both RVI and RVD [143]. Real-time live-cell visualization of Src and Fyn, activation can be achieved [144,145]. <NMMII and smACSK visualization>. To evaluate the forces acting on any singles protein, the molecular tension sensors are being developed [146,147]. As concerns live-cell measurement of ion transport system, activity of NHE1 can be monitored with cSNARF1, a fluorescent sensor of intracellular $\mathrm{pH}[148]$.

\section{Concluding Remarks}

Tight connections between cell volume and cell fate highlight the importance of the search for the molecular apparatus that performs cell volume sensing and regulation. NMMII and F-actin assembly acting together with a PM-smACSK spring seem a promising candidate volume sensor to us. We present an hypothesis that comprises four key features, (1) fine-tuning of cell volume set point (i.e., NMMII, F-actin protrusive activity and viscoelastic properties of PM-SMACSK complex) by cell fate, (2) probing of changes in difference in hydrostatic pressures $\left(\mathrm{HP}_{\text {in }}\right.$ versus $\left.\mathrm{HP}_{\text {out }}\right)$ across the $\mathrm{PM}$ by two active ATP-consuming mechanisms (NMMII and F-actin polymerization), (3) perfect elasticity of the PM-SMACSK complex, allowing its return to normal shape, and (4) sensing of changes in intracellular ionic strength by NMMII and machinery performing F-actin polymerization. Direct associations of NMMII and F-actin with several transmembrane signaling molecules provide the route for signal transduction onto ion transporting systems.

The search for any particular volume-sensitive-or, as we assume here, active, energyconsuming cell volume sensing-molecular apparatus would be of importance for, e.g., anticancer treatment. Uncontrollable cell proliferation, resistance to apoptosis, migrationthese features are among the hallmarks of cancer cell biology [149]. These cancer cell activities are critically dependent on volume regulatory systems, in particular on shifts in the volume set point. Ion channels are involved in the regulation of cell proliferation and apoptosis as well as in cell volume regulation [1,4,6-9]. NMMII and PM-smACSK could be a signaling hub linking execution of cell proliferation, migration and apoptosis to signaling pathways controlling activities of ion channels and transporters. NMMII isoforms appear to regulate the metastatic potential of cancer cells and, thus, to be novel therapeutic targets [150-152]. Our hypothesis on NMMII as a key player in cell volume sensing broadens the spectrum of effects of NMMII in cancer cells. (Patho)physiological roles of NHEs in organ systems - cardiovascular system, brain, kidneys, skeletal muscle, gastrointestinal tract, salivary glands, pancreas, eyes, immune system, reproductive system, bone, skin - were recently reviewed [9]. Our model suggests a mechanism for activation of NHE isoforms by cell shrinkage and swelling.

Author Contributions: Conceptualization, N.B., M.A., A.L. and A.P.; methodology, M.A., A.L. and C.S.; writing-original draft preparation, N.B., M.A., A.L., C.S., E.S., G.U., A.M. and A.P.; writingreview and editing, N.B., M.A., A.L., C.S., E.S., G.U., A.M. and A.P.; visualization, N.B. and E.S.; project administration, A.P.; funding acquisition, A.P. All authors have read and agreed to the published version of the manuscript.

Funding: This research was funded by University of Sassari "Fondo di Ateneo per la ricerca 2020".

Institutional Review Board Statement: Not applicable.

Informed Consent Statement: Not applicable.

Data Availability Statement: Not applicable.

Acknowledgments: We express gratitude to Owen P. Hamill for inspiration for this work.

Conflicts of Interest: The authors declare no conflict of interest. 


\begin{abstract}
Abbreviations
AVD, apoptotic volume decrease; Dbl, diffuse B-cell lymphoma; ELCs, essential light chains; GEFs, guanine nucleotide exchange factors; HCs, heavy chains. HPs, hydrostatic pressures; KCC, $\mathrm{K}^{+}-\mathrm{Cl}^{-}$cotransporters; MACF1, microtubule actin crosslinking factor 1; MAPKs, mitogen-activated protein kinases; MLCK, myosin light chain kinase; MyoGEF, myosin-interacting GEF; $\mathrm{NHE}, \mathrm{Na}^{+} / \mathrm{H}^{+}$ exchangers; NKCC, $\mathrm{Na}^{+}-\mathrm{K}^{+}-2 \mathrm{Cl}^{-}$cotransporters; NMMII, non-muscle myosin II; PAK, p21-activated kinase; PM, plasma membrane; PP2A, protein phosphatase 2A; RLCs, regulatory light chains; ROCK, Rho-associated coiled-coil containing kinase; ROS, reactive oxygen species; RVD, regulatory volume decrease; RVI, regulatory volume increase; smACSK, submembrane actin-based cytoskeleton.
\end{abstract}

\title{
References
}

1. Lang, F.; Ritter, M.; Gamper, N.; Huber, S.; Fillon, S.; Tanneur, V.; Lepple-Wienhues, A.; Szabo, I.; Bulbins, E. Cell Volume in the Regulation of Cell Proliferation and Apoptotic Cell Death. Cell. Physiol. Biochem. 2000, 10, 417-428. [CrossRef] [PubMed]

2. Hoffmann, E.K.; Lambert, I.H.; Pedersen, S.F. Physiology of Cell Volume Regulation in Vertebrates. Physiol. Rev. 2009, 89, 193-277. [CrossRef]

3. Delpire, E.; Gagnon, K.B. Water Homeostasis and Cell Volume Maintenance and Regulation. Curr. Top. Membr. $2018,81,3-52$.

4. Föller, M.; Lang, F. Ion Transport in Eryptosis, the Suicidal Death of Erythrocytes. Front. Cell Dev. Biol. 2020, 8, 597. [CrossRef]

5. Wilson, C.S.; Mongin, A.A. Chapter Eleven-Cell Volume Control in Healthy Brain and Neuropathologies. Curr. Top. Membr. 2018, 81, 385-455.

6. Bortner, C.D.; Cidlowski, J.A. Ions, the Movement of Water and the Apoptotic Volume Decrease. Front. Cell Dev. Biol. 2020, 8, 1415. [CrossRef]

7. Okada, Y.; Okada, T.; Sato-Numata, K.; Islam, M.R.; Ando-Akatsuka, Y.; Numata, T.; Kubo, M.; Shimizu, T.; Kurbannazarova, R.S.; Marunaka, Y.; et al. Cell Volume-Activated and Volume-Correlated Anion Channels in Mammalian Cells: Their Biophysical, Molecular, and Pharmacological Properties. Pharmacol. Rev. 2019, 71, 49-88. [CrossRef]

8. Okada, Y.; Sabirov, R.Z.; Sato-Numata, K.; Numata, T. Cell Death Induction and Protection by Activation of Ubiquitously Expressed Anion/Cation Channels. Part 1: Roles of VSOR/VRAC in Cell Volume Regulation, Release of Double-Edged Signals and Apoptotic/Necrotic Cell Death. Front. Cell Dev. Biol. 2021, 8, 1776. [CrossRef]

9. Pedersen, S.F.; Counillon, L. The SLC9A-C Mammalian $\mathrm{Na}^{+} / \mathrm{H}^{+}$Exchanger Family: Molecules, Mechanisms, and Physiology. Physiol. Rev. 2019, 99, 2015-2113. [CrossRef] [PubMed]

10. Adragna, N.C.; Ferrell, C.M.; Zhang, J.; Di Fulvio, M.; Temprana, C.F.; Sharma, A.; Fyffe, R.E.W.; Cool, D.R.; Lauf, P.K. Signal transduction mechanisms of $\mathrm{K}^{+}-\mathrm{Cl}^{-}$cotransport regulation and relationship to disease. Acta Physiol. 2006, 187, 125-139. [CrossRef] [PubMed]

11. Hoffmann, E.K.; Pedersen, S.F. Shrinkage insensitivity of NKCC1 in myosin II-depleted cytoplasts from Ehrlich ascites tumor cells. Am. J. Physiol. Cell Physiol. 2007, 292, C1854-C1866. [CrossRef] [PubMed]

12. Klein, J.D.; O'Neill, W.C. Volume-sensitive myosin phosphorylation in vascular endothelial cells: Correlation with Na-K-2Cl cotransport. Am. J. Physiol. Cell Physiol. 1995, 269, C1524-C1531. [CrossRef] [PubMed]

13. Di Ciano-Oliveira, C.D.; Sirokmány, G.; Szászi, K.; Arthur, W.T.; Masszi, A.; Peterson, M.; Rotstein, O.D.; Kapus, A. Hyperosmotic stress activates Rho: Differential involvement in Rho kinase-dependent MLC phosphorylation and NKCC activation. Am. J. Physiol. Cell Physiol. 2003, 285, C555-C566. [CrossRef] [PubMed]

14. Di Ciano-Oliveira, C.D.; Lodyga, M.; Fan, L.; Szászi, K.; Hosoya, H.; Rotstein, O.D.; Kapus, A. Is myosin light-chain phosphorylation a regulatory signal for the osmotic activation of the $\mathrm{Na}^{+}-\mathrm{K}^{+}-2 \mathrm{Cl}^{-}$cotransporter? Am. J. Physiol. Cell Physiol. 2005, 289, C68-C81. [CrossRef] [PubMed]

15. Morishima, S.; Shimizu, T.; Kida, H.; Okada, Y. Volume Expansion Sensitivity of Swelling-Activated $\mathrm{Cl}^{-} \mathrm{Channel} \mathrm{in} \mathrm{Human}^{-}$ Epithelial Cells. Jpn. J. Physiol. 2000, 50, 277-280. [CrossRef]

16. Billington, N.; Wang, A.; Mao, J.; Adelstein, R.S.; Sellers, J.R. Characterization of Three Full-length Human Nonmuscle Myosin II Paralogs. J. Biol. Chem. 2013, 288, 33398-33410. [CrossRef]

17. Dulyaninova, N.G.; Bresnick, A.R. The heavy chain has its day. BioArchitecture 2013, 3, 77-85. [CrossRef]

18. Shutova, M.S.; Svitkina, T.M. Common and Specific Functions of Nonmuscle Myosin II Paralogs in Cells. Biochem. Mosc. 2018, 83, 1459-1468. [CrossRef]

19. Sellers, J.R.; Heissler, S.M. Nonmuscle myosin-2 isoforms. Curr. Biol. 2019, 29, R275-R278. [CrossRef]

20. Kamm, K.E.; Stull, J.T. Dedicated myosin light chain kinases with diverse cellular functions. J. Biol. Chem. 2001, 276, 4527-4530. [CrossRef]

21. Hartshorne, D.J.; Ito, M.; Erdodi, F. Myosin light chain phosphatase: Subunit composition, interactions and regulation. J. Muscle Res. Cell Motil. 1998, 19, 325-341. [CrossRef] [PubMed]

22. Hartshorne, D. Myosin phosphatase: Subunits and interactions. Acta Physiol. Scand. 1998, 164, 483-493. [CrossRef]

23. Kiss, A.; Erdődi, F.; Lontay, B. Myosin phosphatase: Unexpected functions of a long-known enzyme. Biochim. Biophys. Acta BBA Mol. Cell Res. 2019, 1866, 2-15. [CrossRef] 
24. Amano, M.; Ito, M.; Kimura, K.; Fukata, Y.; Chihara, K.; Nakano, T.; Matsuura, Y.; Kaibuchi, K. Phosphorylation and activation of myosin by Rho-associated kinase (Rho-kinase). J. Biol. Chem. 1996, 271, 20246-20249. [CrossRef] [PubMed]

25. Kimura, K.; Ito, M.; Amano, M.; Chihara, K.; Fukata, Y.; Nakafuku, M.; Yamamori, B.; Feng, J.; Nakano, T.; Okawa, K. Regulation of myosin phosphatase by Rho and Rho-associated kinase (Rho-kinase). Science 1996, 273, 245-248. [CrossRef]

26. Sanders, L.C.; Matsumura, F.; Bokoch, G.M.; De Lanerolle, P. Inhibition of myosin light chain kinase by p21-activated kinase. Science 1999, 283, 2083-2085. [CrossRef]

27. Van Leeuwen, F.N.; Van Delft, S.; Kain, H.E.; Van Der Kammen, R.A.; Collard, J.G. Rac regulates phosphorylation of the myosin-II heavy chain, actinomyosin disassembly and cell spreading. Nat. Cell Biol. 1999, 1, 242-248. [CrossRef] [PubMed]

28. Giannone, G.; Dubin-Thaler, B.J.; Rossier, O.; Cai, Y.; Chaga, O.; Jiang, G.; Beaver, W.; Döbereiner, H.-G.; Freund, Y.; Borisy, G. Lamellipodial actin mechanically links myosin activity with adhesion-site formation. Cell 2007, 128, 561-575. [CrossRef] [PubMed]

29. Baird, M.A.; Billington, N.; Wang, A.; Adelstein, R.S.; Sellers, J.R.; Fischer, R.S.; Waterman, C.M. Local pulsatile contractions are an intrinsic property of the myosin 2A motor in the cortical cytoskeleton of adherent cells. Mol. Biol. Cell 2016, 28, 240-251. [CrossRef]

30. Schmidt, A.; Hall, A. Guanine nucleotide exchange factors for Rho GTPases: Turning on the switch. Genes Dev. 2002, 16, 1587-1609. [CrossRef]

31. Toma-Fukai, S.; Shimizu, T. Structural Insights into the Regulation Mechanism of Small GTPases by GEFs. Molecules 2019, 24, 3308. [CrossRef] [PubMed]

32. Rossman, K.L.; Der, C.J.; Sondek, J. GEF means go: Turning on RHO GTPases with guanine nucleotide-exchange factors. Nat. Rev. Mol. Cell Biol. 2005, 6, 167-180. [CrossRef] [PubMed]

33. Lee, C.-S.; Choi, C.-K.; Shin, E.-Y.; Schwartz, M.A.; Kim, E.-G. Myosin II directly binds and inhibits Dbl family guanine nucleotide exchange factors: A possible link to Rho family GTPases. J. Cell Biol. 2010, 190, 663-674. [CrossRef] [PubMed]

34. Bokoch, G.M. Biology of the p21-activated kinases. Annu. Rev. Biochem. 2003, 72, 743-781. [CrossRef]

35. Sander, E.E.; ten Klooster, J.P.; van Delft, S.; van der Kammen, R.A.; Collard, J.G. Rac downregulates Rho activity: Reciprocal balance between both GTPases determines cellular morphology and migratory behavior. J. Cell Biol. 1999, 147, $1009-1022$. [CrossRef] [PubMed]

36. Nimnual, A.S.; Taylor, L.J.; Bar-Sagi, D. Redox-dependent downregulation of Rho by Rac. Nat. Cell Biol. 2003, 5, $236-241$. [CrossRef]

37. Wu, D.; Asiedu, M.; Adelstein, R.; Wei, Q. A Novel Guanine Nucleotide Exchange Factor, MyoGEF, is Required for Cytokinesis. Cell Cycle 2006, 5, 1234-1239. [CrossRef] [PubMed]

38. Hamill, O.P.; Martinac, B. Molecular basis of mechanotransduction in living cells. Physiol. Rev. 2001, 81, 685-740. [CrossRef]

39. Jacobs, M.L.; Faizi, H.A.; Peruzzi, J.A.; Vlahovska, P.M.; Kamat, N.P. EPA and DHA differentially modulate membrane elasticity in the presence of cholesterol. Biophys. J. 2021, 120, 2317-2329. [CrossRef]

40. Barvitenko, N.; Aslam, M.; Lawen, A.; Pantaleo, A.; Saldanha, C.; Matteucci, E. Effects of oxygen depletion on transmembrane protein activities. Curr. Org. Chem. 2015, 19, 2002-2010. [CrossRef]

41. Bennett, V.; Baines, A.J. Spectrin and ankyrin-based pathways: Metazoan inventions for integrating cells into tissues. Physiol. Rev. 2001, 81, 1353-1392. [CrossRef]

42. Kapus, A.; Janmey, P. Plasma membrane-Cortical cytoskeleton interactions: A cell biology approach with biophysical considerations. Compr. Physiol. 2013, 3, 1231-1281. [PubMed]

43. Mohandas, N.; Gallagher, P.G. Red cell membrane: Past, present, and future. Blood 2008, 112, 3939-3948. [CrossRef]

44. de Oliveira, S.; Saldanha, C. An overview about erythrocyte membrane. Clin. Hemorheol. Microcirc. 2010, 44, 63-74. [CrossRef]

45. de Oliveira, S.; Silva-Herdade, A.S.; Saldanha, C. Modulation of erythrocyte deformability by PKC activity. Clin. Hemorheol. Microcirc. 2008, 39, 363-373. [CrossRef]

46. Saldanha, C.; Silva, A.S.; Gonçalves, S.; Martins-Silva, J. Modulation of erythrocyte hemorheological properties by band 3 phosphorylation and dephosphorylation. Clin. Hemorheol. Microcirc. 2007, 36, 183-194.

47. de Almeida, J.P.L.; Freitas-Santos, T.; Saldanha, C. Erythrocyte deformability dependence on band 3 protein in an in-vitro model of hyperfibrinogenemia. Clin. Hemorheol. Microcirc. 2012, 50, 213-219. [CrossRef]

48. Pantaleo, A.; Ferru, E.; Pau, M.C.; Khadjavi, A.; Mandili, G.; Mattè, A.; Spano, A.; De Franceschi, L.; Pippia, P.; Turrini, F. Band 3 Erythrocyte Membrane Protein Acts as Redox Stress Sensor Leading to Its Phosphorylation by $\mathrm{p}^{72}$ Syk. Oxid. Med. Cell. Longev. 2016, 2016, 6051093. [CrossRef] [PubMed]

49. Ferru, E.; Giger, K.; Pantaleo, A.; Campanella, E.; Grey, J.; Ritchie, K.; Vono, R.; Turrini, F.; Low, P.S. Regulation of membranecytoskeletal interactions by tyrosine phosphorylation of erythrocyte band 3. Blood 2011, 117, 5998-6006. [CrossRef] [PubMed]

50. Hu, L.; Huang, Z.; Wu, Z.; Ali, A.; Qian, A. Mammalian plakins, giant cytolinkers: Versatile biological functions and roles in cancer. Int. J. Mol. Sci. 2018, 19, 974. [CrossRef]

51. Hu, L.; Su, P.; Li, R.; Yin, C.; Zhang, Y.; Shang, P.; Yang, T.; Qian, A. Isoforms, structures, and functions of versatile spectraplakin MACF1. BMB Rep. 2016, 49, 37. [CrossRef]

52. Barvitenko, N.; Lawen, A.; Aslam, M.; Pantaleo, A.; Saldanha, C.; Skverchinskaya, E.; Regolini, M.; Tuszynski, J.A. Integration of intracellular signaling: Biological analogues of wires, processors and memories organized by a centrosome 3D reference system. Comput. Theor. Exp. Approaches Morphog. 2018, 173, 191-206. [CrossRef] 
53. Pollard, T.D.; Borisy, G.G. Cellular Motility Driven by Assembly and Disassembly of Actin Filaments. Cell 2003, $112,453-465$. [CrossRef]

54. Svitkina, T.M. Ultrastructure of protrusive actin filament arrays. Curr. Opin. Cell Biol. 2013, 25, 574-581. [CrossRef]

55. Svitkina, T.M. Ultrastructure of the actin cytoskeleton. Curr. Opin. Cell Biol. 2018, 54, 1-8. [CrossRef]

56. Lieber, A.D.; Yehudai-Resheff, S.; Barnhart, E.L.; Theriot, J.A.; Keren, K. Membrane Tension in Rapidly Moving Cells Is Determined by Cytoskeletal Forces. Curr. Biol. 2013, 23, 1409-1417. [CrossRef]

57. Tong, J.; Li, L.; Ballermann, B.; Wang, Z. Phosphorylation of Rac1 T108 by extracellular signal-regulated kinase in response to epidermal growth factor: A novel mechanism to regulate Rac1 function. Mol. Cell. Biol. 2013, 33, 4538-4551. [CrossRef]

58. Tong, J.; Li, L.; Ballermann, B.; Wang, Z. Phosphorylation and activation of RhoA by ERK in response to epidermal growth factor stimulation. PLoS ONE 2016, 11, e0147103. [CrossRef]

59. Wee, P.; Wang, Z. Epidermal growth factor receptor cell proliferation signaling pathways. Cancers 2017, 9, 52. [CrossRef]

60. Lemmon, M.A.; Schlessinger, J. Cell Signaling by Receptor Tyrosine Kinases. Cell 2010, 141, 1117-1134. [CrossRef]

61. Somlyo, A.P.; Somlyo, A.V. Signal transduction by G-proteins, rho-kinase and protein phosphatase to smooth muscle and non-muscle myosin II. J. Physiol. 2000, 522, 177-185. [CrossRef]

62. Ridley, A.J. Rho GTPase signalling in cell migration. Cell Adhes. Migr. 2015, 36, 103-112. [CrossRef] [PubMed]

63. Wang, J.; Zhang, L.; Qu, R.; Zhang, L.; Huang, W. Rho A Regulates Epidermal Growth Factor-Induced Human Osteosarcoma MG63 Cell Migration. Int. J. Mol. Sci. 2018, 19, 1437. [CrossRef] [PubMed]

64. Kakiashvili, E.; Dan, Q.; Vandermeer, M.; Zhang, Y.; Waheed, F.; Pham, M.; Szászi, K. The Epidermal Growth Factor Receptor Mediates Tumor Necrosis Factor- $\alpha$-induced Activation of the ERK/GEF-H1/RhoA Pathway in Tubular Epithelium. J. Biol. Chem. 2011, 286, 9268-9279. [CrossRef]

65. Rao, T.C.; Ma, V.P.-Y.; Blanchard, A.; Urner, T.M.; Grandhi, S.; Salaita, K.; Mattheyses, A.L. EGFR activation attenuates the mechanical threshold for integrin tension and focal adhesion formation. J. Cell Sci. 2020, 133, jcs238840. [CrossRef]

66. Bagnato, A.; Rosanò, L. New Routes in GPCR/ $\beta$-Arrestin-Driven Signaling in Cancer Progression and Metastasis. Front. Pharmacol. 2019, 10, 114. [CrossRef]

67. Vázquez-Juárez, E.; Ramos-Mandujano, G.; Hernández-Benítez, R.; Pasantes-Morales, H. On the Role of G-Protein Coupled Receptors in Cell Volume Regulation. Cell. Physiol. Biochem. 2008, 21, 001-014. [CrossRef]

68. Rubtsova, S.N.; Zhitnyak, I.Y.; Gloushankova, N.A. Phenotypic Plasticity of Cancer Cells Based on Remodeling of the Actin Cytoskeleton and Adhesive Structures. Int. J. Mol. Sci. 2021, 22, 1821. [CrossRef]

69. Friedl, P.; Alexander, S. Cancer Invasion and the Microenvironment: Plasticity and Reciprocity. Cell 2011, 147, 992-1009. [CrossRef]

70. Schwab, A.; Fabian, A.; Hanley, P.J.; Stock, C. Role of Ion Channels and Transporters in Cell Migration. Physiol. Rev. 2012, 92, 1865-1913. [CrossRef]

71. Ridley, A.J.; Schwartz, M.A.; Burridge, K.; Firtel, R.A.; Ginsberg, M.H.; Borisy, G.; Parsons, J.T.; Horwitz, A.R. Cell migration: Integrating signals from front to back. Science 2003, 302, 1704-1709. [CrossRef] [PubMed]

72. Raftopoulou, M.; Hall, A. Cell migration: Rho GTPases lead the way. Dev. Biol. 2004, 265, 23-32. [CrossRef]

73. Straussman, R.; Even, L.; Ravid, S. Myosin II heavy chain isoforms are phosphorylated in an EGF-dependent manner: Involvement of protein kinase C. J. Cell Sci. 2001, 114, 3047-3057. [CrossRef]

74. Kolega, J. Asymmetric distribution of myosin IIB in migrating endothelial cells is regulated by a rho-dependent kinase and contributes to tail retraction. Mol. Biol. Cell 2003, 14, 4745-4757. [CrossRef]

75. Kolega, J. The role of myosin II motor activity in distributing myosin asymmetrically and coupling protrusive activity to cell translocation. Mol. Biol. Cell 2006, 17, 4435-4445. [CrossRef] [PubMed]

76. Sandquist, J.C.; Means, A.R. The C-Terminal Tail Region of Nonmuscle Myosin II Directs Isoform-specific Distribution in Migrating Cells. Mol. Biol. Cell 2008, 19, 5156-5167. [CrossRef]

77. Vicente-Manzanares, M.; Zareno, J.; Whitmore, L.; Choi, C.K.; Horwitz, A.F. Regulation of protrusion, adhesion dynamics, and polarity by myosins IIA and IIB in migrating cells. J. Cell Biol. 2007, 176, 573-580. [CrossRef]

78. Wang, Y.; Xu, Y.; Liu, Q.; Zhang, Y.; Gao, Z.; Yin, M.; Jiang, N.; Cao, G.; Yu, B.; Cao, Z.; et al. Myosin IIA-related Actomyosin Contractility Mediates Oxidative Stress-induced Neuronal Apoptosis. Front. Mol. Neurosci. 2017, 10, 75. [CrossRef]

79. Lang, E.; Qadri, S.M.; Zelenak, C.; Gu, S.; Rotte, A.; Draeger, A.; Lang, F. Inhibition of suicidal erythrocyte death by blebbistatin. Am. J. Physiol. Cell Physiol. 2011, 301, C490-C498. [CrossRef]

80. Gao, S.; Cheng, C.; Wang, M.; Jiang, P.; Zhang, L.; Wang, Y.; Wu, H.; Zeng, X.; Wang, H.; Gao, X.; et al. Blebbistatin Inhibits Neomycin-Induced Apoptosis in Hair Cell-Like HEI-OC-1 Cells and in Cochlear Hair Cells. Front. Cell. Neurosci. 2020, 13, 590. [CrossRef]

81. Schein, S.J.; Colombini, M.; Finkelstein, A. Reconstitution in planar lipid bilayers of a voltage-dependent anion-selective channel obtained from paramecium mitochondria. J. Membr. Biol. 1976, 30, 99-120. [CrossRef]

82. De Pinto, V.; Messina, A.; Lane, D.J.; Lawen, A. Voltage-dependent anion-selective channel (VDAC) in the plasma membrane. FEBS Lett. 2010, 584, 1793-1799. [CrossRef]

83. Lisanti, M.P.; Scherer, P.E.; Vidugiriene, J.; Tang, Z.; Hermanowski-Vosatka, A.; Tu, Y.-H.; Cook, R.F.; Sargiacomo, M. Characterization of caveolin-rich membrane domains isolated from an endothelial-rich source: Implications for human disease. J. Cell Biol. 1994, 126, 111-126. [CrossRef] 
84. Fernandez-Echevarria, C.; Díaz, M.; Ferrer, I.; Canerina-Amaro, A.; Marin, R. A $\beta$ promotes VDAC1 channel dephosphorylation in neuronal lipid rafts. Relevance to the mechanisms of neurotoxicity in Alzheimer's disease. Neuroscience 2014, 278, 354-366. [CrossRef]

85. Okada, S.F.; O’Neal, W.K.; Huang, P.; Nicholas, R.A.; Ostrowski, L.E.; Craigen, W.J.; Lazarowski, E.R.; Boucher, R.C. Voltagedependent anion channel-1 (VDAC-1) contributes to ATP release and cell volume regulation in murine cells. J. Gen. Physiol. 2004, 124, 513-526. [CrossRef] [PubMed]

86. Xu, X.; Forbes, J.; Colombini, M. Actin modulates the gating of Neurospora crassa VDAC. J. Membr. Biol. 2001, 180, 73-81. [CrossRef]

87. Roman, I.; Figys, J.; Steurs, G.; Zizi, M. Direct measurement of VDAC-actin interaction by surface plasmon resonance. Biochim. Biophys. Acta BBA Biomembr. 2006, 1758, 479-486. [CrossRef] [PubMed]

88. Elinder, F.; Akanda, N.; Tofighi, R.; Shimizu, S.; Tsujimoto, Y.; Orrenius, S.; Ceccatelli, S. Opening of plasma membrane voltagedependent anion channels (VDAC) precedes caspase activation in neuronal apoptosis induced by toxic stimuli. Cell Death Differ. 2005, 12, 1134-1140. [CrossRef]

89. Grinthal, A.; Adamovic, I.; Weiner, B.; Karplus, M.; Kleckner, N. PR65, the HEAT-repeat scaffold of phosphatase PP2A, is an elastic connector that links force and catalysis. Proc. Natl. Acad. Sci. USA 2010, 107, 2467-2472. [CrossRef]

90. Liedtke, C.M.; Wang, X.; Smallwood, N.D. Role for Protein Phosphatase 2A in the Regulation of Calu-3 Epithelial Na+ $-\mathrm{K}^{+}-2 \mathrm{Cl}^{-}$, Type 1 Co-transport Function. J. Biol. Chem. 2005, 280, 25491-25498. [CrossRef]

91. Bize, I.; Güvenç, B.; Buchbinder, G.; Brugnara, C. Stimulation of Human Erythrocyte K-Cl Cotransport and Protein Phosphatase Type 2A by n-Ethylmaleimide: Role of Intracellular Mg++. J. Membr. Biol. 2000, 177, 159-168. [CrossRef]

92. Fowler, V.M.; Davis, J.Q.; Bennett, V. Human erythrocyte myosin: Identification and purification. J. Cell Biol. 1985, 100, 47-55. [CrossRef]

93. Smith, A.S.; Nowak, R.B.; Zhou, S.; Giannetto, M.; Gokhin, D.S.; Papoin, J.; Ghiran, I.C.; Blanc, L.; Wan, J.; Fowler, V.M. Myosin IIA interacts with the spectrin-actin membrane skeleton to control red blood cell membrane curvature and deformability. Proc. Natl. Acad. Sci. USA 2018, 115, E4377-E4385. [CrossRef]

94. Straussman, R.; Squire, J.M.; Ben-Ya'acov, A.; Ravid, S. Skip residues and charge interactions in myosin II coiled-coils: Implications for molecular packing. J. Mol. Biol. 2005, 353, 613-628. [CrossRef] [PubMed]

95. Rosenberg, M.; Straussman, R.; Ben-Ya'acov, A.; Ronen, D.; Ravid, S. MHC-IIB filament assembly and cellular localization are governed by the rod net charge. PLoS ONE 2008, 3, e1496. [CrossRef]

96. Schroer, C.F.E.; Baldauf, L.; van Buren, L.; Wassenaar, T.A.; Melo, M.N.; Koenderink, G.H.; Marrink, S.J. Charge-dependent interactions of monomeric and filamentous actin with lipid bilayers. Proc. Natl. Acad. Sci. USA 2020, 117, 5861-5872. [CrossRef]

97. Beck, M.R.; Dixon, R.D.S.; Goicoechea, S.M.; Murphy, G.S.; Brungardt, J.G.; Beam, M.T.; Srinath, P.; Patel, J.; Mohiuddin, J.; Otey, C.A.; et al. Structure and Function of Palladin's Actin Binding Domain. J. Mol. Biol. 2013, 425, 3325-3337. [CrossRef]

98. Yamamoto, E.; Domański, J.; Naughton, F.B.; Best, R.B.; Kalli, A.C.; Stansfeld, P.J.; Sansom, M.S. Multiple lipid binding sites determine the affinity of PH domains for phosphoinositide-containing membranes. Sci. Adv. 2020, 6, eaay5736. [CrossRef]

99. Cox, C.D.; Bavi, N.; Martinac, B. Biophysical Principles of Ion-Channel-Mediated Mechanosensory Transduction. Cell Rep. 2019, 29, 1-12. [CrossRef]

100. Martinac, B.; Bavi, N.; Ridone, P.; Nikolaev, Y.A.; Martinac, A.D.; Nakayama, Y.; Rohde, P.R.; Bavi, O. Tuning ion channel mechanosensitivity by asymmetry of the transbilayer pressure profile. Biophys. Rev. 2018, 10, 1377-1384. [CrossRef]

101. Senju, Y.; Lappalainen, P. Regulation of actin dynamics by PI $(4,5)$ P2 in cell migration and endocytosis. Curr. Opin. Cell Biol. 2019, 56, 7-13. [CrossRef]

102. Murakami, N.; Elzinga, M.; Singh, S.S.; Chauhan, V.P. Direct binding of myosin II to phospholipid vesicles via tail regions and phosphorylation of the heavy chains by protein kinase C. J. Biol. Chem. 1994, 269, 16082-16090. [CrossRef]

103. Murakami, N.; Singh, S.S.; Chauhan, V.P.S.; Elzinga, M. Phospholipid binding, phosphorylation by protein kinase C, and filament assembly of the $\mathrm{COOH}$ terminal heavy chain fragments of nonmuscle myosin II isoforms MIIA and MIIB. Biochemistry 1995, 34, 16046-16055. [CrossRef]

104. Li, D.; Miller, M.; Chantler, P.D. Association of a cellular myosin II with anionic phospholipids and the neuronal plasma membrane. Proc. Natl. Acad. Sci. USA 1994, 91, 853-857. [CrossRef]

105. Liu, X.; Shu, S.; Billington, N.; Williamson, C.D.; Yu, S.; Brzeska, H.; Donaldson, J.G.; Sellers, J.R.; Korn, E.D. Mammalian Nonmuscle Myosin II Binds to Anionic Phospholipids with Concomitant Dissociation of the Regulatory Light Chain. J. Biol. Chem. 2016, 291, 24828-24837. [CrossRef]

106. Koe, C.T.; Tan, Y.S.; Lönnfors, M.; Hur, S.K.; Low, C.S.L.; Zhang, Y.; Kanchanawong, P.; Bankaitis, V.A.; Wang, H. Vibrator and PI4KIII $\alpha$ govern neuroblast polarity by anchoring non-muscle myosin II. eLife 2018, 7, e33555. [CrossRef]

107. Alexander, S.; Mathie, A.; Peters, J. Ion channels. Br. J. Pharmacol. 2011, 164, S137-S174. [CrossRef]

108. Jensen, C.S.; Watanabe, S.; Rasmussen, H.B.; Schmitt, N.; Olesen, S.-P.; Frost, N.A.; Blanpied, T.A.; Misonou, H. Specific Sorting and Post-Golgi Trafficking of Dendritic Potassium Channels in Living Neurons. J. Biol. Chem. 2014, 289, 10566-10581. [CrossRef]

109. Dash, B.; Dib-Hajj, S.D.; Waxman, S.G. Multiple myosin motors interact with sodium/potassium-ATPase alpha 1 subunits. Mol. Brain 2018, 11, 45. [CrossRef]

110. Marquèze-Pouey, B.; Martin-Moutot, N.; Sakkou-Norton, M.; Lévêque, C.; Ji, Y.; Cornet, V.; Hsiao, W.L.; Seagar, M. Toxicity and Endocytosis of Spinocerebellar Ataxia Type 6 Polyglutamine Domains: Role of Myosin IIB ${ }^{\dagger}$. Traffic 2008, 9, 1088-1100. [CrossRef] 
111. Stritt, S.; Nurden, P.; Favier, R.; Favier, M.; Ferioli, S.; Gotru, S.K.; van Eeuwijk, J.M.M.; Schulze, H.; Nurden, A.T.; Lambert, M.P.; et al. Defects in TRPM7 channel function deregulate thrombopoiesis through altered cellular Mg2+ homeostasis and cytoskeletal architecture. Nat. Commun. 2016, 7, 11097. [CrossRef] [PubMed]

112. Bachmann, M.; Kukkurainen, S.; Hytönen, V.P.; Wehrle-Haller, B. Cell adhesion by integrins. Physiol. Rev. 2019, 99, 1655-1699. [CrossRef]

113. Häussinger, D.; Reinehr, R.; Schliess, F. The hepatocyte integrin system and cell volume sensing. Acta Physiol. 2006, 187, 249-255. [CrossRef] [PubMed]

114. vom Dahl, S.; Schliess, F.; Reissmann, R.; Görg, B.; Weiergräber, O.; Kocalkova, M.; Dombrowski, F.; Häussinger, D. Involvement of Integrins in Osmosensing and Signaling toward Autophagic Proteolysis in Rat Liver. J. Biol. Chem. 2003, 278, 27088-27095. [CrossRef] [PubMed]

115. Pedersen, S.F.; Kapus, A.; Hoffmann, E.K. Osmosensory Mechanisms in Cellular and Systemic Volume Regulation. J. Am. Soc. Nephrol. 2011, 22, 1587-1597. [CrossRef]

116. Schedlbauer, A.; Tamma, G.; Rodighiero, S.; Civello, D.A.; Tamplenizza, M.; Ledolter, K.; Nofziger, C.; Patsch, W.; Konrat, R.; Paulmichl, M.; et al. Binding of the protein ICln to $\alpha$-integrin contributes to the activation of IClswell current. Sci. Rep. 2019, 9, 12195. [CrossRef]

117. Girault, A.; Chebli, J.; Privé, A.; Trinh, N.T.N.; Maillé, E.; Grygorczyk, R.; Brochiero, E. Complementary roles of KCa3.1 channels and $\beta 1$-integrin during alveolar epithelial repair. Respir. Res. 2015, 16, 100. [CrossRef]

118. Sørensen, B.H.; Rasmussen, L.J.H.; Broberg, B.S.; Klausen, T.K.; Sauter, D.P.R.; Lambert, I.H.; Aspberg, A.; Hoffmann, E.K. Integrin $\beta 1$, Osmosensing, and Chemoresistance in Mouse Ehrlich Carcinoma Cells. Cell. Physiol. Biochem. 2015, 36, 111-132. [CrossRef]

119. Artym, V.V.; Petty, H.R. Molecular Proximity of Kv1.3 Voltage-gated Potassium Channels and $\beta 1$-Integrins on the Plasma Membrane of Melanoma Cells: Effects of Cell Adherence and Channel Blockers. J. Gen. Physiol. 2002, 120, 29-37. [CrossRef]

120. Levite, M.; Cahalon, L.; Peretz, A.; Hershkoviz, R.; Sobko, A.; Ariel, A.; Desai, R.; Attali, B.; Lider, O. Extracellular K+ and Opening of Voltage-Gated Potassium Channels Activate T Cell Integrin Function: Physical and Functional Association between Kv1.3 Channels and $\beta 1$ Integrins. J. Exp. Med. 2000, 191, 1167-1176. [CrossRef]

121. Sajid, M.; Hu, Z.; Lele, M.; Stouffer, G. Protein complexes involving alpha v beta 3 integrins, nonmuscle myosin heavy chain-A, and focal adhesion kinase from in thrombospondin-treated smooth muscle cells. J. Investig. Med. Off. Publ. Am. Fed. Clin. Res. 2000, 48, 190-197.

122. Rosado, L.A.R.; Horn, T.A.; McGrath, S.C.; Cotter, R.J.; Yang, J.T. Association between $\alpha 4$ integrin cytoplasmic tail and non-muscle myosin IIA regulates cell migration. J. Cell Sci. 2011, 124, 483-492. [CrossRef]

123. Morin, N.A.; Oakes, P.W.; Hyun, Y.-M.; Lee, D.; Chin, Y.E.; King, M.R.; Springer, T.A.; Shimaoka, M.; Tang, J.X.; Reichner, J.S.; et al. Nonmuscle myosin heavy chain IIA mediates integrin LFA-1 de-adhesion during T lymphocyte migration. J. Exp. Med. 2008, 205, 195-205. [CrossRef]

124. Schlaepfer, D.D.; Hanks, S.K.; Hunter, T.; van der Geer, P. Integrin-mediated signal transduction linked to Ras pathway by GRB2 binding to focal adhesion kinase. Nature 1994, 372, 786-791. [CrossRef] [PubMed]

125. Jeong, S.-J.; Kim, S.-G.; Yoo, J.; Han, M.-Y.; Park, J.-C.; Kim, H.-J.; Kang, S.S.; Choi, B.-D.; Jeong, M.-J. Increased association of dynamin II with myosin II in ras transformed NIH3T3 cells. Acta Biochim. Biophys. Sin. 2006, 38, 556-562. [CrossRef]

126. Xu, Z.; Li, P.; Wei, D.; Wang, Z.; Bao, Y.; Sun, J.; Qu, L.; Wang, L. NMMHC-IIA-dependent nuclear location of CXCR4 promotes migration and invasion in renal cell carcinoma. Oncol. Rep. 2016, 36, 2681-2688. [CrossRef] [PubMed]

127. Spano, J.-P.; Andre, F.; Morat, L.; Sabatier, L.; Besse, B.; Combadiere, C.; Deterre, P.; Martin, A.; Azorin, J.; Valeyre, D.; et al. Chemokine receptor CXCR4 and early-stage non-small cell lung cancer: Pattern of expression and correlation with outcome. Ann. Oncol. 2004, 15, 613-617. [CrossRef]

128. Shrivastava, S.; Sarkar, P.; Preira, P.; Salomé, L.; Chattopadhyay, A. Role of Actin Cytoskeleton in Dynamics and Function of the Serotonin1A Receptor. Biophys. J. 2020, 118, 944-956. [CrossRef] [PubMed]

129. Lezama, R.; Díaz-Téllez, A.; Ramos-Mandujano, G.; Oropeza, L.; Pasantes-Morales, H. Epidermal Growth Factor Receptor is a Common Elementin the Signaling Pathways Activated by Cell Volume Changes in Isosmotic, Hyposmotic or Hyperosmotic Conditions. Neurochem. Res. 2005, 30, 1589-1597. [CrossRef]

130. Di Blasio, L.; Gagliardi, P.A.; Puliafito, A.; Primo, L. Serine/threonine kinase 3-phosphoinositide-dependent protein kinase-1 (PDK1) as a key regulator of cell migration and cancer dissemination. Cancers 2017, 9, 25. [CrossRef] [PubMed]

131. Franco, R.; Lezama, R.; Ordaz, B.; Pasantes-Morales, H. Epidermal growth factor receptor is activated by hyposmolarity and is an early signal modulating osmolyte efflux pathways in Swiss 3T3 fibroblasts. Pflüg. Arch. 2004, 447, 830-839. [CrossRef] [PubMed]

132. Tanaka, M.; Konishi, H.; Touhara, K.; Sakane, F.; Hirata, M.; Ono, Y.; Kikkawa, U. Identification of Myosin II as a Binding Protein to the PH Domain of Protein Kinase B. Biochem. Biophys. Res. Commun. 1999, 255, 169-174. [CrossRef]

133. Milburn, C.C.; Deak, M.; Kelly, S.M.; Price, N.C.; Alessi, D.R.; van Aalten, D.M.F. Binding of phosphatidylinositol 3,4,5trisphosphate to the pleckstrin homology domain of protein kinase B induces a conformational change. Biochem. J. 2003, 375, 531-538. [CrossRef]

134. Lowenstein, E.; Daly, R.; Batzer, A.; Li, W.; Margolis, B.; Lammers, R.; Ullrich, A.; Skolnik, E.; Bar-Sagi, D.; Schlessinger, J. The SH2 and SH3 domain-containing protein GRB2 links receptor tyrosine kinases to ras signaling. Cell 1992, 70, 431-442. [CrossRef]

135. Yoon, S.Y.; Koh, W.S.; Lee, M.K.; Park, Y.M.; Han, M.Y. Dynamin II Associates with Grb2 SH3 Domain in Ras Transformed NIH3T3 Cells. Biochem. Biophys. Res. Commun. 1997, 234, 539-543. [CrossRef] [PubMed] 
136. Kranenburg, O.; Moolenaar, W.H. Ras-MAP kinase signaling by lysophosphatidic acid and other G protein-coupled receptor agonists. Oncogene 2001, 20, 1540-1546. [CrossRef]

137. Lee, K.-J.; Kim, Y.; Kim, M.S.; Ju, H.-M.; Choi, B.; Lee, H.; Jeoung, D.; Moon, K.-W.; Kang, D.; Choi, J.; et al. CD99-PTPN12 Axis Suppresses Actin Cytoskeleton-Mediated Dimerization of Epidermal Growth Factor Receptor. Cancers 2020, 12, 2895. [CrossRef] [PubMed]

138. Kohlstedt, K.; Kellner, R.; Busse, R.; Fleming, I. Signaling via the Angiotensin-Converting Enzyme Results in the Phosphorylation of the Nonmuscle Myosin Heavy Chain IIA. Mol. Pharmacol. 2006, 69, 19-26. [CrossRef]

139. Fisher, S.K.; Cheema, T.A.; Foster, D.J.; Heacock, A.M. Volume-dependent osmolyte efflux from neural tissues: Regulation by G-protein-coupled receptors. J. Neurochem. 2008, 106, 1998-2014. [CrossRef]

140. Erdogmus, S.; Storch, U.; Danner, L.; Becker, J.; Winter, M.; Ziegler, N.; Wirth, A.; Offermanns, S.; Hoffmann, C.; Gudermann, T.; et al. Helix 8 is the essential structural motif of mechanosensitive GPCRs. Nat. Commun. 2019, 10, 5784. [CrossRef]

141. Zhou, Y.; Meng, J.; Xu, C.; Liu, J. Multiple GPCR Functional Assays Based on Resonance Energy Transfer Sensors. Front. Cell Dev. Biol. 2021, 9, 779. [CrossRef] [PubMed]

142. Adjobo-Hermans, M.J.; Goedhart, J.; van Weeren, L.; Nijmeijer, S.; Manders, E.M.; Offermanns, S.; Gadella, T.W. Real-time visualization of heterotrimeric $\mathrm{G}$ protein $\mathrm{Gq}$ activation in living cells. BMC Biol. 2011, 9, 32. [CrossRef] [PubMed]

143. Cohen, D.M. SRC family kinases in cell volume regulation. Am. J. Physiol. Cell Physiol. 2005, 288, C483-C493. [CrossRef]

144. Vetter, M.L.; Zhang, Z.; Liu, S.; Wang, J.; Cho, H.; Zhang, J.; Zhang, W.; Gray, N.S.; Yang, P.L. Fluorescent Visualization of Src by Using Dasatinib-BODIPY. ChemBioChem 2014, 15, 1317-1324. [CrossRef]

145. Mukherjee, A.; Singh, R.; Udayan, S.; Biswas, S.; Reddy, P.P.; Manmadhan, S.; George, G.; Kumar, S.; Das, R.; Rao, B.M.; et al. A Fyn biosensor reveals pulsatile, spatially localized kinase activity and signaling crosstalk in live mammalian cells. eLife 2020, 9, e50571. [CrossRef] [PubMed]

146. Ham, T.R.; Collins, K.L.; Hoffman, B.D. Molecular tension sensors: Moving beyond force. Mol. Cell. Single Mol. Technol. Neural Eng. High Resolut. Cell Imaging 2019, 12, 83-94. [CrossRef]

147. Lavrenyuk, K.; Conway, D.; Dahl, K.N. Imaging methods in mechanosensing: A historical perspective and visions for the future. Mol. Biol. Cell 2021, 32, 842-854. [CrossRef]

148. Richards, M.A.; Simon, J.N.; Ma, R.; Loonat, A.A.; Crabtree, M.J.; Paterson, D.J.; Fahlman, R.P.; Casadei, B.; Fliegel, L.; Swietach, P. Nitric oxide modulates cardiomyocyte $\mathrm{pH}$ control through a biphasic effect on sodium/hydrogen exchanger-1. Cardiovasc. Res. 2020, 116, 1958-1971. [CrossRef] [PubMed]

149. Hanahan, D.; Weinberg, R.A. Hallmarks of cancer: The next generation. Cell 2011, 144, 646-674. [CrossRef]

150. Surcel, A.; Schiffhauer, E.S.; Thomas, D.G.; Zhu, Q.; DiNapoli, K.T.; Herbig, M.; Otto, O.; West-Foyle, H.; Jacobi, A.; Kräter, M.; et al. Targeting Mechanoresponsive Proteins in Pancreatic Cancer: 4-Hydroxyacetophenone Blocks Dissemination and Invasion by Activating MYH14. Cancer Res. 2019, 79, 4665-4678. [CrossRef]

151. Bryan, D.S.; Stack, M.; Krysztofiak, K.; Cichoń, U.; Thomas, D.G.; Surcel, A.; Schiffhauer, E.S.; Beckett, M.A.; Khodarev, N.N.; Xue, L.; et al. 4-Hydroxyacetophenone modulates the actomyosin cytoskeleton to reduce metastasis. Proc. Natl. Acad. Sci. USA 2020, 117, 22423-22429. [CrossRef]

152. Naydenov, N.G.; Lechuga, S.; Huang, E.H.; Ivanov, A.I. Myosin Motors: Novel Regulators and Therapeutic Targets in Colorectal Cancer. Cancers 2021, 13, 741. [CrossRef] 